\title{
Production and Technology of Iron and Steel in Japan during 1980
}

\section{By Tsuneyo IKI*}

\section{Introduction}

In 1980 Japanese economy showed two distinct features, one during the first half and the other in the latter half. The period from January to March, as continuation of expansive economy activity in the private sector in 1979 in spite of the Government's efforts to mitigate the shock of the soaring oil price, the economic growth rate turned out to be a high $7.4 \%$.

However, as a result of the decrease in actual purchasing power accompanying the commodity prices increase and scalingdown of public works expenditure, the actual growth rate in the April to June period slowed down to $2.5 \%$ by the annual rate. Facing this unfavorable situation, the Government tried to stimulate the economic activity by lowering the official discount rate of the Bank of Japan by $0.75 \%$ to $8.25 \%$ in August 19, releasing in September some of the public works spending programs hitherto held up and other measures. Nevertheless, at this moment, the general economic trend in Japan and the world is not much encouraging. It is highly probable that the slow or little growth rate will be prolonged through 1981 and thereafter in industrialized countries.

Reflecting this situation the iron and steel industry of Japan showed a similar trend as described above. Around the middle of 1980 the demand and supply relation began to be bearish, let us follow this trend. In the first quarter (from January to March) of 1980, the domestic demand for steel mainly from shipbuilding industry and electric home appliances industry, stayed active in spite of the Government's unti-inflation policy. In addition, the inventory increasing demand from other industries grew unticipating an impending substantial increase in electricity price to be set by the Government. As a result, even though the demand from abroad, particularly from the United States and China, decreased considerably due to their economic hardship, the crude steel output during this quarter kept the same level as that of the previous quarter (October to December, 1979). In the April to June quarter, the real domestic demand showed a large decrease by a reaction to the inventory increase in the previous quarter as well as by slackening in the housing and construction activities due to the suspension of the Government's spending on public works. Exports did not pick up either. Nevertheless, the crude steel output increased remarkably and recorded the 9th consecutive quarterly growth. However, such increased crude steel output did not hold and had to be reduced in response to the real decreased demand. Thus the output in the July to September quarter recorded the lowest point since the January to March quarter of 1978. Although the civil engineering sector may show the seasonal pick-up during the October to December quarter, the building and housing sector destined to be very sluggish. Consequently the crude steel output is unticipated to show a decrease during the two consecutive quarters. The statistics shows that quarterly crude steel output in 1980 was 28.46 million MT for the first quarter, 29.28 million MT for the second, and 27.33 million MT for the third.

In the iron and steel technology, on the other hand, there has been a steady progress. For example, the iron and steel firms showed much emphasis on rationalization and labor reduction primarily by introducing various innovations centering around continuous casting facilities. They also put in practice wider use of computer control of plant operations better utilization of materials and energy and development of environmental technology.

Looking at these efforts in terms of equipment investment, however, one notices that the 1980 expenditure is estimated to be 594.1 billion yen, approximately $7.3 \%$ decrease from the estimated actual investiment of 640.8 billion of 1979 . This decrease owes largely to the fact that construction of the new blast furnaces in Ohgishima Works was nearly completed by 1979. If this factor is set aside, the 1980 investment can be said to have increased by $20 \%$ from that of the previous year, a sign of resumption of active investment movement. Much investment was directed to rationalization and to labor reduction facilities as well as revamping and maintenance works, but some investment for new facilities to meet changing demand pattern is also included. The investment in energy saving facilities was approximately $9 \%$ of the total, but if the fact that the amount of equipment investment indirectly relating to energy saving one way or others was as high as $52.1 \%$ is considered, one may conclude the rate of the energy conscious investment was on upward trend again in 1980. With regard to the investment in environmental facilities it decreased to $4.7 \%$ of the total. This was the first time since 1971 that the rate became below $10 \%$. The low record is explained by the fact that environmental facilities to be added to the existing production plants facilities had almost been completed and that there was no significant new installation for production expansion. Although in 1980 there was

* Chief Secretary, The Joint Research Society, The Iron and Steel Institute of Japan, Otemachi, Chiyoda-ku, Tokyo 100. 


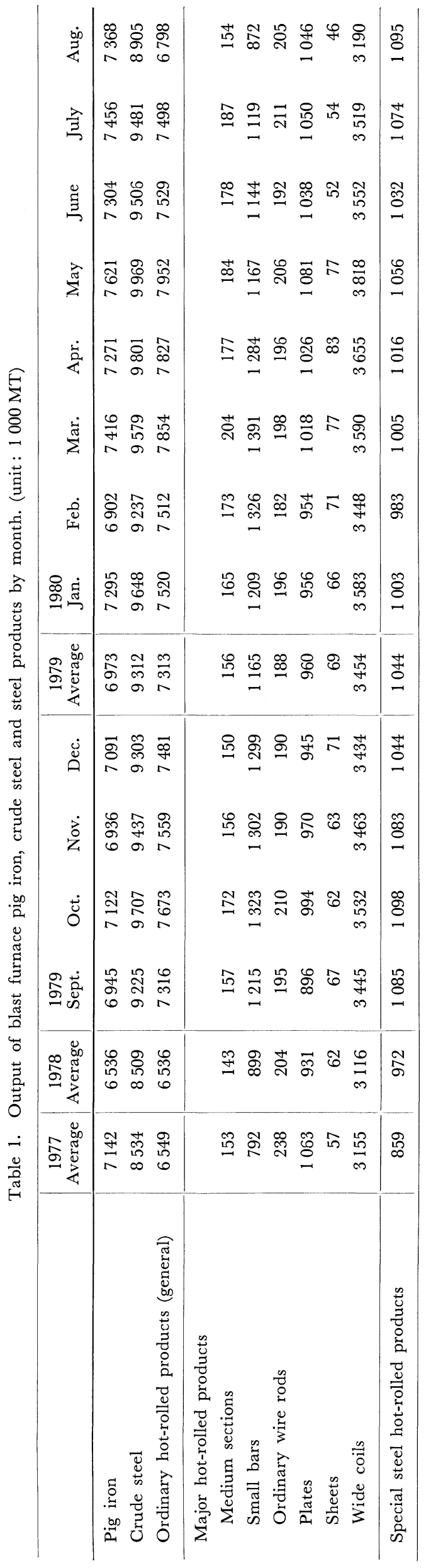

no remarkable developments like the completion of Ohgishima No. 2 Blast Furnace of Keihin Works, Nippon Kokan K.K. in 1979, the iron and steel industry is looked upon to have played the leading role in the investment related to energy utilization.

\section{Technology and Facilities}

\section{Ironmaking}

One of the most outstanding features of the iron and steel industry in the past 10 years is the construction of large blast furnaces. Today nearly $50 \%$ of Japanese blast furnaces is of an inner volume of $4000 \mathrm{~m}^{3}$ or more. With the blowing-in of Ohgishima No. $2 \mathrm{BF}$ (inner volume of $4052 \mathrm{~m}^{3}$ ) in July 1979 , the number of $4000 \mathrm{~m}^{3}$ class blast furnaces in Japan increased to 15. As of October 1980 the operating rate of these large size blast furnaces is $87.3 \%$ (13 in operation) in terms of the inner volume. For comparison, at the end of 1978, all 14 blast furnaces of $4000 \mathrm{~m}^{3}$ class were in full operation. As for blast furnaces of $2000 \mathrm{~m}^{3}$ or less, the operation rate has been decreasing year after year since 1970 when it was $97 \%$. Today about half of those existing small BFs are not working.

Table 2 shows the recent blast furnace operation records. The fuel ratio (coke plus oil), often taken as an indicator of the level of ironmaking technology, was $472 \mathrm{~kg} / \mathrm{MT}$ in 1977, $467 \mathrm{~kg} / \mathrm{MT}$ in 1978 and 461 $\mathrm{kg} / \mathrm{MT}$ in 1979, showing a result of tenacious and strenuous endeavor to overcome the industry's fate which is not blessed with domestic raw materials and energy. This endeavor is reflected in the improvement of operation technology in general such as improvment of reduction efficiency using high temperature blast, dehydration of blast, rational pretreatment of raw materials and most suitable distribution of burden with the aid of movable armors and bell-less rotating chutes. Looking at the monthly record of fuel ratio during 1980, one notices an upward trend. This is attributed to the less use of fuel oil for lessening the dependence on oil as will be discussed later.

One of the blast furnaces recording steady decrease of fuel ratio for a long time is the No. $3 \mathrm{BF}$ (inner volume of $5050 \mathrm{~m}^{3}$ ) of Kashima Steel Works, Sumitomo Metal Industries, Ltd., the world's largest BF, completed in September, 1976. This BF recorded an average annual ratio of $447.5 \mathrm{~kg} / \mathrm{MT}$ of hot metal in 1979, the third concecutive year when less than $450 \mathrm{~kg} / \mathrm{MT}$ was achieved succeeding $449.7 \mathrm{~kg} / \mathrm{MT}$ in 1977, the lowest record achieved by any large size blast furnace for the first time and $446.3 \mathrm{~kg} / \mathrm{MT}$ in 1978. Particular attention should be called here that this excellent record was achieved where the sintered ore mixing rate, a very important factor for low fuel ratio, was as low as $70 \%$ and the use of fuel oil was restrained considerably (40 kg/MT in 1977, $25 \mathrm{~kg} /$ $\mathrm{MT}$ in 1978 and $13 \mathrm{~kg} / \mathrm{MT}$ in 1979). The reasons for this achievement are as follows:

1) Optimal distribution of raw materials with movable armor together with optimal blast furnace gas distribution with the aid of various sensors (im- 
provement in gas utilization ratio and reduction of furnace wall heat loading);

2) Continuous stable use of high temperature blast and effective use of dehydrated blast;

3) Long range stabulization of operation through periodical joint discussion between research staff from the Central Research Laboratories and Kashima Steel Works' plant engineers (analysis of blast furnace operation theory using computers and setup of operational guide for optimal use of liquid fuel;

4) Improvement of reducibility of sintered ore; and

5) Stabilization of hot metal and slag tapping operations owing to BF workers.

It should be mentioned also that in No. 1 BF (inner volume of $3680 \mathrm{~m}^{3}$ ) of Kashima Steel Works blown-in in December 1979 the fuel ratio achieved the landmark of less than $440 \mathrm{~kg} / \mathrm{MT}$ in the eleventh month after its blowing-in (namely, $438.9 \mathrm{~kg} / \mathrm{MT}$ with a fuel oil ratio of $25.8 \mathrm{~kg} / \mathrm{MT}$ ). As a result the works established the record of all BFs' average monthly fuel ratio of $444.1 \mathrm{~kg} / \mathrm{MT}$ in December, 1979.

The No. 4 BF $\left(2290 \mathrm{~m}^{3}\right)$ of Muroran Works, Nippon Steel Corp. recorded in September 1980 the lowest monthly fuel ratio of $408 \mathrm{~kg} / \mathrm{MT}$. This figure is very close to the theoretically conceivable minimum of 400 to $405 \mathrm{~kg} / \mathrm{MT}$. (Prior to this, the record was $418 \mathrm{~kg} / \mathrm{MT}$ achieved by No. 6 BF of Chiba Works, Kawasaki Steel Corp. in March 1980.) The reasons for this achievement are attributed to the employment of low $\mathrm{SiO}_{2}$ low $\mathrm{FeO}$ sintered ore, the use of low ash high strength coke, the merit of improved cokemaking technology based on charging of pre-heated coal, and the use of new operation adjusted to grain size of sintered ore for each of few blast furnaces. The preheated coal charging coke ovens in question is the No. 6 Coke Ovens of Muroran Works, which has been operating since October 1979 as replacement of the No. 2. The improved coke properties are already mentioned above, and this coke ovens are the first in Japan employing the pre-carbon process (introduced from Berkwerks-Verrband (BWV) and DiDier of F. R. Germany in February 1975) known for good environmental protection effects. Here, the coal is pre-heated at $220^{\circ}$ to $230^{\circ} \mathrm{C}$ before charging to coke ovens in a closed chain conveyer. With the introduction of this process, up to $20 \%$ of good quality coal can be replaced by lower grade coal. Further the productivity of the coke ovens is improved by $35 \%$. The No. 6 Coke Ovens of Muroran Works employed this process (1) to adopt Nippon Steel M type coke oven design, (2) to use thinner walls at carburization chambers for improvement of heat transfer, (3) to employ process computers for control of pre-heating process and coke oven operation and (4) to reduce labor requirement.

In order to meet the unstable and high priced oil supply in recent years blast furnace ironmakers have been trying to use fuel oil as little as possible aiming at an all coke or "oil-less" operation. The decrease of the ratio of fuel oil injected to blast furnaces has been rapid: from $58 l / \mathrm{MT}$ of hot metal in 1973 to $38 l$ in 1977, $37 l$ in 1978 and $31 l$ in 1979. This trend was so much intensified in 1980 that it reached $17 l$ in August.

Ohgishima No. 1 BF $\left(4052 \mathrm{~m}^{3}\right)$ of Keihin Works, Nippon Kokan K.K. started all coke operation in April; this means that all the 5 BFs (3 223, 4 288, 4617,4052 and $4052 \mathrm{~m}^{3}$ ) of the Works are now in the oil-less operation (3 using coke only and 2 coke and tar). No. 5 BF (2 $\left.584 \mathrm{~m}^{3}\right)$ of Chiba Works, Kawasaki Steel Corp., which was blown-in on October 6 after re-lining since June 1977 is operating on an all-coke basis. In addition to being non-dependent on oil, this blast furnace is noted for its energy saving on the top pressure recovery power generation $(9200 \mathrm{~kW} \times 1)$ and the hot stove waste gas recovery as well as recycling of gas cleaning water.

Thus, the number of blast furnaces in operation on an oil-less basis is 20 for all coke and 6 for coke-tar among the 44 blast furnaces in operation as of May 1980. However, since extensive replacement of fuel oil with coke tends to bring about not only economically negative factors of the increase of fuel ratio but also technical difficulties such as delicate control of temperature in front of tuyeres, some firms are studying the coal and oil mixtures (COM), the coal and tar mixtures (CTM), and the pulverized coal injection (PGI).

Sumitomo Metal Industries Ltd., who has been developing COM injecting technique since 1977, started in August 1980 on-site COM manufacturing and injection in its Kashima No. $1 \mathrm{BF}\left(3680 \mathrm{~m}^{3}\right)$, then in September, a test of continuous injection to 3 tuyeres $(1 \mathrm{MT} / \mathrm{hr}$ ) was initiated. This is the first time in the world that COM was used in a large, high pressure blast furnace of $3000 \mathrm{~m}^{3}$ or more.

The test comprises following items.

1) Practical tests on manufacturing, conveyance and distribution control technology at $1 \mathrm{MT} / \mathrm{hr}$.

2) Preliminary test for injecting to all tuyeres (20 MT/hr) scheduled in 1981.

With respect to practical utilization of PGI technique, Nippon Steel Corp. imported Armco Steel's PGI technique after a joint feasibility study on large blast furnaces conducted in Japan. Reaching a conclusion that this technique is applicable even to a modern large size BFs, Nippon Steel Corp. started the fabrication of the first equipment for their Oita No. 1 BF $\left(4158 \mathrm{~m}^{3}\right)$ in August to be completed in June 1981.

Kobe Steel, Ltd., on the other hand, imported a technique for equal distribution of pulverized coal to each tuyere, the greatest importance in the PCI technique, from Petrocarb of the United States. Combining this with other techniques already developed for their own, they have established their own comprehensive PGI technique, which will be practically applied to the Kobe No. 3 BF $\left(1845 \mathrm{~m}^{3}\right)$ in April 1982.

The advantages of PCI technique are, first, comparing with all-coke operation, the productivity of BF's effective volume will be increased by 10 to $20 \%$ just as in the case of injecting fuel oil, and, second, the 


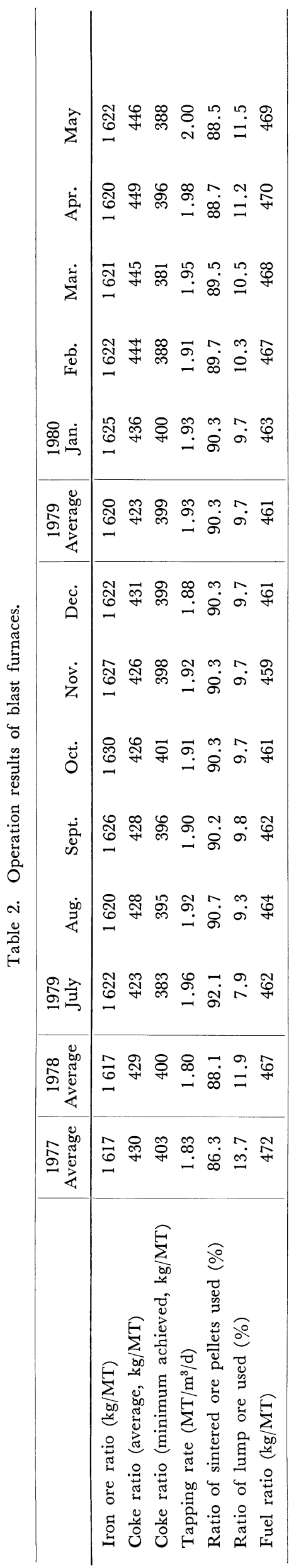

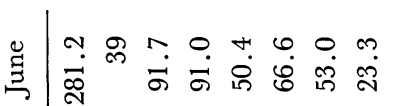

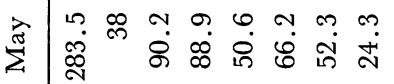

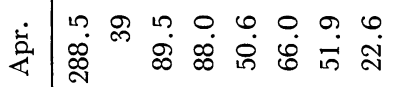

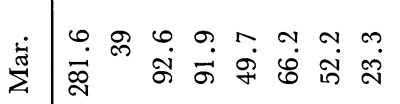

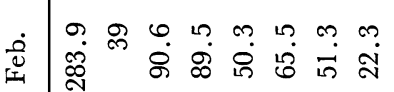

品峦

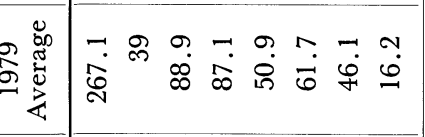

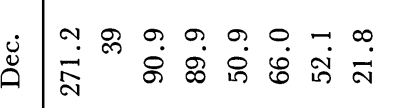

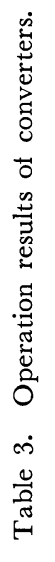

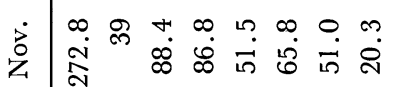

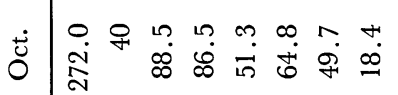

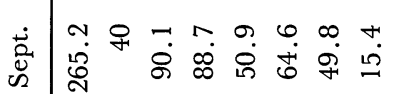

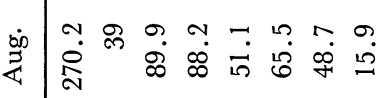

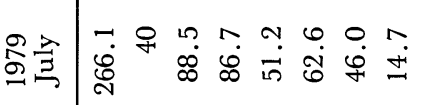

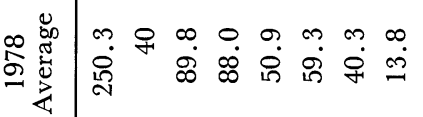

若

?

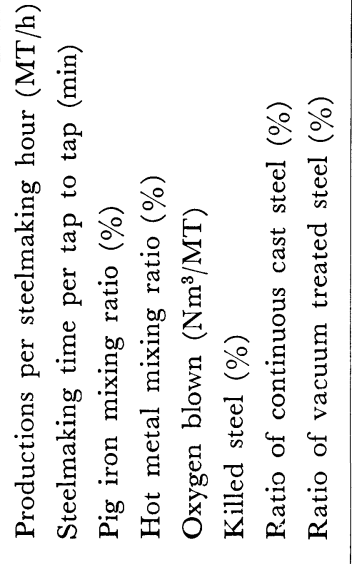

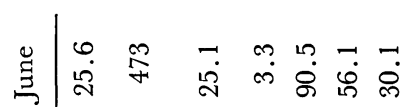

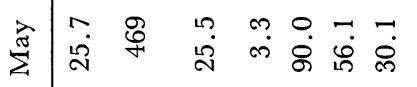

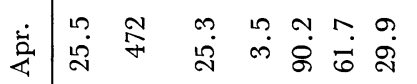

节

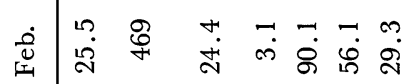

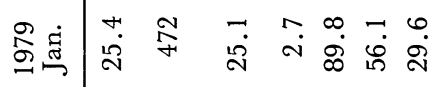

芴

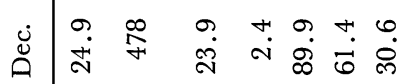

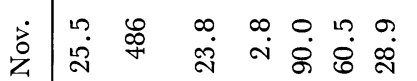

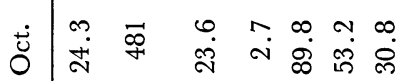

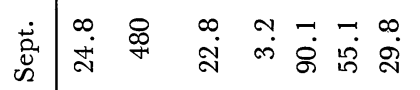

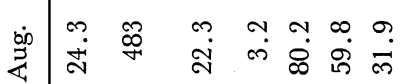

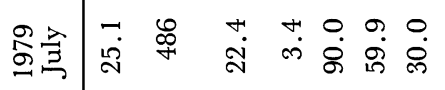

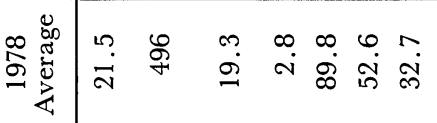

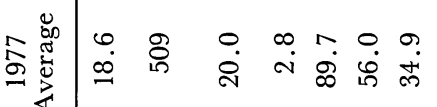

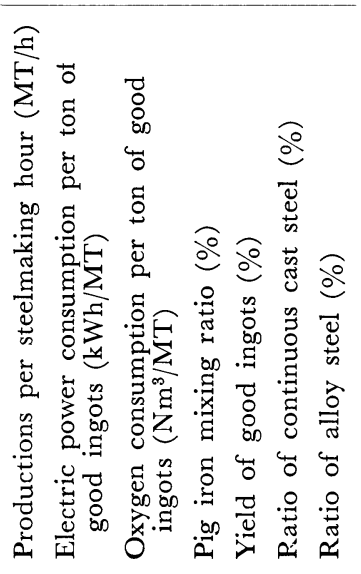


coke ratio in the fuel ratio will be lowered.

Among notable achievements in the BF technology of 1980 there is the relining work done in Kakogawa No. 2 BF $\left(3850 \mathrm{~m}^{3}\right)$, Kobe Steel, Ltd. by its own working force. The BF was blown down in March 1978, and since then with 16.5 billion yen expenditure the relining was completed by the end of 1979 and reblown-in in February 1980. Although the firm previously made their relining work by its own working force on medium and small furnaces (inner volume of less than $2000 \mathrm{~m}^{3}$ ) at Kobe and Amagasaki Works, its was the first time that they have done it on a large furnace. Following the example of Kakogawa No. $3 \mathrm{BF}\left(4500 \mathrm{~m}^{3}\right)$ the relined No. 2 is equipped with a hot stove waste heat recovery system, and the top-pressure power generating system $(14000 \mathrm{~kW})$. The latter used to serve No. $1 \mathrm{BF}$ $\left(3090 \mathrm{~m}^{3}\right.$ ) also was made exclusive to No. 2 BF. Further, by the improvement of charging control system better operational stability and the extended furnace life are expected, while an atop-the-building electric dust precipitator featured in it is something new.

\section{Steelmaking}

The recent trends in steelmaking are found in the converter performance (Table 3) and in the electric furnace performance (Table 4). The ratios of killed steel, continuously cast steel and vacuum treated steel are increasing. Another recent trend is the installation of large production facilities, for example, as of the end of 1979 there were 11 with a volume of $500 \mathrm{~m}^{3}$ or more and 38 of $300 \mathrm{~m}^{3}$ or more among 93 existing converters.

In the field of converter steelmaking, a new refining process called "LD-OB" (pure oxygen top and bottom blowing) is attracting much attention. Comparing with the conventional LD process, in this new process, a part of oxygen passes through tuyeres provided at the bottom. This brings the effect of better stirring of the bath, resulting in improved molten steel yield and decrease of ferroalloy requirement as well as lowered oxygen and nitrogen contents in the molten steel.

In the light of the encouraging development results of this process carried out in September 1979, Nippon Steel Corp. went ahead to its practical application, by remodeling No. 3 converter (150 MT) of No. 1 Steel Shop and No. 1 converter (320 MT) of No. 3 Steel Shop of Yawata Works and No. 3 converter (340 MT) of Oita Works for regular production.

No. 4 converter (250 MT) of No. 2 Steel Shop of Mizushima Works, Kawasaki Steel Corp. is carrying out test operation of pure oxygen top and bottom blowing. The characteristics of Kawasaki process, which they call the K-BOP, are that less than $40 \%$ of the total oxygen is blown with a protection gas from several double-wall tube tuyeres at the bottom, and that lime powder is injected together with oxygen gas. This firm is well known to have achieved much in the field of bottom blowing process and intent on further development works. Nippon Kokan K.K. is also practicing a top and bottom oxygen blowing process in No. 1 converter (180 MT) of No. 1 Steel Shop in Fukuyama Works since April, 1980.

Sumitomo Metal Industries' " combined top and bottom blow refining process", which they were experimenting with a $15 \mathrm{MT}$ mini-plant for improving the yield and the composition control as well as economizing auxiliary materials, has been practically applied to 2 converters (250 MT) of No. 2 Steel Shop at Kashima Steel Works in March, 1980. This process has the following characteristics:

(1) Several percents of the total necessary oxygen amount and some amount of inert gas are blown from the bottom for the purpose of stirring the bath during refining, resulting in decrease of iron oxidation loss, prevention of the local temperature rise at oxygen injection spot, promotion of mixing of steel and slag and accelerated decarburization for low carbon steel melting.

(2) The stirring gas is blown through the doublewall-tube tuyeres, oxygen and inert gas from the inner tube and inert gas from the outer tube. Although usually argon or hydrocarbon is used as the inert gas, this firm uses $\mathrm{CO}_{2}$. This means not only an economy, but $\mathrm{CO}_{2}$ is more effective for preventing solidified steel from internal cracking vulnerability due to increase of hydrogen content coming from hydrocarbon.

(3) $\mathrm{CO}_{2}$ gas to be blown is acquired through this firm's proprietary process which converts converter recovery gas ( $K$ gas) into $\mathrm{H}_{2}$ and $\mathrm{CO}_{2}$, accordingly this process constitutes a part of integrated converter gas utilization system.

As for new converter construction installed in 1980 a 150 tonner started operation at Kure Works, Nisshin Steel Co., Ltd on January 12, 1980, together with expansion of its continuous casting capacity for reducing the overall production cost. The construction cost was approximately 19 billion yen. The monthly production is 100000 MT initially but is expected to be $215000 \mathrm{MT}$ ultimately.

Efforts for improving the hitting rate of chemical analysis and end temperature to ascertain the completion of blowing are continually made by all firms. Their sub-lance techniques and dynamic control systems based on such techniques are receiving high recognition from abroad.

One notable new steelmaking technology is the manufacturing of " extremely low phosphorous, sulfur and hydrogen steels" developed by Kawasaki Steel Corp. at Mizushima Works. It is a converter-ladlerefining furnace-vacuum ingotmaking process to provide exceptionally low phosphorus, sulfur and hydrogen steels for large forged stocks such as rotor shaft for generators. Various techniques are incorporated as follows:

1) Fully automated blowing system in a converter utilizing the lance vibration aiming at quick slag making and consequent fast dephosphorization of bath.

2) Strengthening of stirring of slag and molten steel for increased bath dephosphorization. 
3) The use of the newly developed dephosphorization agent to intensify dephosphorization in ladle.

4) A technique to prevent rephosphorization during refining in the ladle.

5) A new vacuum ingotmaking technique for prevention of penetration of hydrogen in solidifying ingot.

Thanks to the application of these techniques phosphorus content is reduced to $0.002 \%$, sulfur to $0.001 \%$ and hydrogen to $0.4 \mathrm{ppm}$. Hitherto, such very low $\mathrm{P}, \mathrm{S}, \mathrm{H}$ steels had been made by carrying out dephosphorization and desulfurization by LD converter or electric furnace-ladle refining furnaceordinary ingotmaking route followed by dehydration in the succeeding annealing process. With the development of this new route the electric furnace process and dehydration annealing process are no longer required. Another advantage is the provision of large ingots up to the capacity of ladle refining furnace, i.e., up to $100 \mathrm{MT}$, no longer limited by the capacity of electric furnace (30 MT/charge).

In the field of electric furnace operations, productivity has been improved rapidly in recent years. Average consumption of electricity per MT of good ingot was $483 \mathrm{kWh}$ in $1979,21 \mathrm{kWh}$ decrease from 1977. This trend was apparent again in 1980, achieving in February and in May a figure as low as $469 \mathrm{kWh}$. This is principally attributed to replacement of small furnaces by new large furnace (50 to 150 MT class), spreading of UHP (ultrahigh power operation), employment of optimal power consumption control system, automated principal and auxiliary materials charging processes, use of secondary refining facilities and introduction of sliding nozzle.

Tokyo Steel Manufacturing Co., Ltd. is planning to install a new $70 \mathrm{MT}$ electric furnace at its Tsukuba Works as replacement of a 50 tonner of Ishinomaki Works, while Kokko Steel Works Ltd. is planning to install a 70 tonner at its main works to replace two existing 30 tonners.

\section{Continuous Casting and Slabbing}

Comparing with the conventional ingotmaking process, the continuous casting process has become more widely adopted today throughout the world because of the advantages it offers in eliminating ingotmaking, slabbing and soaking processes, and of better yield, less energy and higher productivity. Particularly Japanese steel firms are enthusiastic about the wider and more use of this process as shown in Tables 3 and 4: in 1979 the ratios of continuous casting in converter killed steel and electric furnace steel were $46.1 \%$ and $58.8 \%$, respectively, and the number of continuous casting facilities has been increasing from 39 in 1970 to 122 in 1975 and 137 in 1980. The number of continuous bloom/billet casting machine for independent electric furnace mills, in particular, has increased more than four times as many as that in 10 years ago, from 18 in 1970 to 82 as of January 1980.

An outstanding continuous casting ratio record of 90.5\% was established in March 1980 by Mizushima
Works, Kawasaki Steel Corp., which is well known in eagerness of increasing continuous casting ratio and the record holder at $87.2 \%$ established in December 1979. This achievement is remarkable because the products mix of the Works is wide ranging from plates and sheets to shapes and wire rods. Technical factors behind this achievement are as follows.

1) Quality improvement (less segregations and less internal cracks) and high speed casting due to installation of an ASEA type electro-magnetic stirring for the No. 1 C.C. (for bloom).

2) Establishment of techniques for sequence continuous casting of various types at No. 6 G.C. (slabs width up to $2500 \mathrm{~mm}$ ) in addition to the already versatile No. 2 (for slab), No. 3 (for large bloom) and No. 5 (slab).

3) Accomplishment by the No. 5 C.C. of a continuous casting rate (the ratio of actual operating time to calender time) of $92.9 \%$ under the conditions of various qualities and changes of width during casting.

Major new facilities installed during 1980 include the No. 2 C.C. of No. 2 Steel Shop of Kimitsu Works, Nippon Steel Corp., which was completed in April. The machine is a vertical bending 2 strand type slab caster with a monthly production capacity of $210000 \mathrm{MT}$ and equipped with RH type vacuum degassing vessel (same capacity) and a computer control system. The products-mix ranges widely from high grade plates for line pipes to various hot and cold rolled products.

Other new installations are Sumitomo Metal Industries' continuous bloom caster of a monthly production capacity of $36000 \mathrm{MT}$ at No. 1 Steel Shop of Wakayama Steel Works, and Nippon Steel's curved bending type 2 strand C.C. with a monthly production capacity of $200000 \mathrm{MT}$ at No. 2 Steel Shop of Nagoya Works.

Speaking of new techniques in the continuous casting, a horizontal continuous caster in the stage of pilot plant, experiment in Sumitomo Metal Industries' Steel Tube Works is to be mentioned. The development is being carried out on two classes of machines, one for high speed operation as in the case of slabs for hot rolling involving high investment, and the other for the low cost machine suitable for varied small lot steels.

Another topic is Kawasaki Steel's (Mizushima Works) new special one-layer alloy plating (tough alloy plating called "TAP") of a superior wear resistance for mold in continuous casting. This technique is appreciated in the stable and improved surface quality with a low cost of maintenance.

\section{Rolling}

In the field of rolling, technological development is directed towards larger facilities, higher speed, better quality, further continuity and less energy consumption, combined with utilization of computers.

In the energy saving, the Plate Mill of Oita Works, Nippon Steel Corp. established in February a new record of reheating furnaces fuel consumption of 
$256000 \mathrm{kcal} / \mathrm{MT}$ of slab, some $100000 \mathrm{kcal}$ lower than the average of 350000 to $360000 \mathrm{kcal}$. The Plate Mill which started operation in January 1977, recorded $280000 \mathrm{kcal}$ in November 1977, then 261000 $\mathrm{kcal}$ in March 1978. These records are owing to the various measures including Jishukanri, such as decrease of oxygen percentage in waste gas, reduction of unit consumption heat by improved accuracy of necessary holding and heating time during downtime and employment of the jet preheater using waste gas heat.

Sakai Works, Nippon Steel Corp. established in May the supposedly world's best record of 124000 $\mathrm{kcal} / \mathrm{MT}$ for the hot strip mill soaking pit. In this works the Heavy Shape Mill and the Hot Strip Mill already realized in November 1979 the then best record of $137000 \mathrm{kcal} / \mathrm{MT}$ and $135000 \mathrm{kcal} / \mathrm{MT}$ at the same time. This Works is also well known for initiation of direct rolling (ingots from a soaking pit is without reheating rolled into plate or shape) resulting in very small unit heat in the reheating furnaces. The major reasons behind are;

1) raising of direct rolling ratio to $87 \%$ for large shapes and $72 \%$ for hot coils,

2) computer control of soaking schedule, and

3) optimal air-to-fuel ratio operation.

Nippon Steel Corp. also established the best record of $209000 \mathrm{kcal} / \mathrm{MT}$ of wire rod billet rolling in April 1980 at its Kamaishi Works.

In the field of yield raising, Kawasaki Steel Corp. achieved the supposedly world's best plate yield of $94.2 \%$ in January 1980, at No. 2 Plate Mill of Mizushima Works. The newly developed profile and shape control process (MAS rolling) and the fast response hydraulic screw-down device that replaced the conventional electric type, contributed greatly to this high yield.

As for the new rolling technology, the rolling of continuously cast slab into large $\mathrm{H}$ shapes and automatic control of looperless rolling are to be mentioned. The rolling technique of large $\mathrm{H}$ shapes from slabs (not blooms) developed by Kawasaki Steel Corp. at Mizushima Works is the first of the kind in the world. This technique may be called an epochmaking. Conventionally the continuous casting for large $\mathrm{H}$ shapes $(600 \mathrm{~mm}$ or more in web and $400 \mathrm{~mm}$ or more in flange) requires a large beam blank casting machine with very special mold and other expensive facilities. Therefore, the large $\mathrm{H}$ shapes use to be manufactured through ingotmaking and blooming processes. With this new technique shown in Fig. 1. It will be seen that edging of slab is so extensive that a width large enough for flange is provided, and then it is processed by caliber into the beam blank. The advantages of this technique are; (1) simplification and reduction of variety of semi-products in stock yards, (2) improvement in surface and internal properties of products, and (3) considerable reduction of production cost.

Since 1977 Nippon Steel Corp. has been developing a looperless rolling control technique for hot strip mill in collaboration with Toshiba Corp. at Muroran Works and with Mitsubishi Electric Corp. and Hitachi Ltd. at Yawata Works. Through these experimental operations they came to the conclusion that the practical application is feasible. The looperless rolling means elimination of loopers which are installed for tension control between stands. In the new process rolling force detected by a load cell at each stand and voltage, current and speed indications by mill motor setup are used for computation of tension by a computer using a mathematical model. Comparing the value thus obtained with the target tension value stored in the computer the deviation is fed back on-line to the rolling speed control system of the mill motor. With this arrangement, the whole set of loopers and related devices can be omitted, consequently the mill layout will become simpler and the equipment cost will be less than conventional mills. Further it will ensure less fuel consumptions at reheating furnaces and better rolling yield since the fast response tension control enables much stronger screwdown in the finishing line.

Sumitomo Metal Industries, Ltd., developed with success their variable crown roll (VG Roll) for a 4-high mill at Wakayama Steel Works. This is an extension of the practical advantage demonstrated already in 2-high temper mill to the 4-high finishing plate mill. This brought about favorable effects on reduction of offgauge product together with less down time.

\section{Measuring and Controlling}

Use of computers, which is already prevalent in iron and steel works may be classified into four fields. Firstly, they are used for material flow control. They search possible bottle-necks in the flow of materials among processes such as ironmaking, steelmaking, slabbing, rolling, finishing and shipping, and issue warning signs if and when existing flow is deviated from the pre-determined plans.

Sumitomo Metal Industries, Ltd. in cooperation with Nippon Electric Co., Ltd. developed and put into practice at the Kashima Steel Works "In-plant Material Flow and Shipping On-line System ". This system aims at reduction of stock in shipping yards,

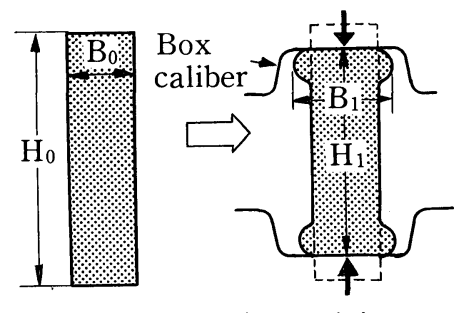

Continously cast slab

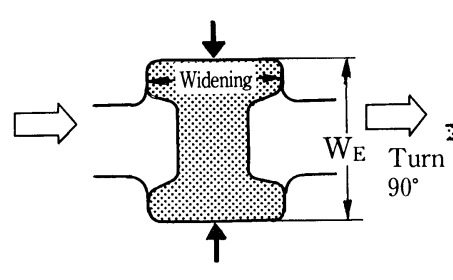

Edging completed

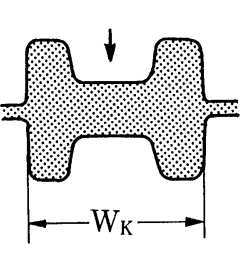

Beam blank caliber rolling
Fig. 1.

Rolling of large $\mathrm{H}$ shapes out of continuously cast slab. 
saving of labor, reduction of conveyance cost and accuracy of delivery schedule from order reception to shipping.

Secondly, computers are employed for quality control such as computation of charge blending, control of in-furnace combustion of coke and other fuels, plotting of quality control charts for ensuring stable quality at intermediate stages, automation of production facilities in accordance with the work directives, comprehensive analysis of production data, examination of inspection data for final products and decision on approval or rejection at shipping. Sumitomo Metal Industries, Ltd. developed at Wakayama Steel Works' hot strip mill an unique rolling system called "Hops" based upon high performance automatic gauge control devices (AGG), and hydraulic loopers for control of tension between finishing stands. Further, the Works is extending the computer control to the pipe manufacturing process, which is rather neglected up to now, for example, a seamless pipe line is now under its own automatic thickness control system.

Thirdly, there are computer control systems for energy distribution. They supervise energy saving installations and dictate optimal adjustment of demand and supply of all energy sources. Nippon Steel Corp. at Nagoya Works developed an " energy demand/supply, plan system" and put into practice in April 1980.

In this system real time data on production processes (100 lines and facilities) and energy sources (11 kinds) are compiled by computers on-line to prepare an energy supply and demand plan which is displayed graphically and in printed form. Using this information the staffs in charge of production, scheduling and energy management decide jointly an optimal production plan.

Fourthly, there are computers for integrated information control. They are used as on-line data processors from order receiving to shipping so as to maintain a proper linkage and a close cross-communication among various production plants and sales offices for a smooth execution of operation plans. An additional advantage in having an integrated data base lies in its utilization as a data bank for technological supervision and cost control overall plants and offices for analytical and managerial researches.

Most of the newly constructed plants are designed to take the best advantage of computers and can benefit from it as mentioned above. But for old plants, hasty introduction of computers often show unsatisfactory results. It is quite necessary to find some particular know-how when the computer technology is introduced to the existing facilities. Researches on this problem should be undertaken further.

\section{Exportation of Technology and Technical Cooperation}

The iron and steel industry of Japan has been receiving a world-wide recognition for their high productivity achieved in spite of problems of stagnant demand for steel, environmental restrictions, excessive production capacity, the adverse international climate of limited oil supply, rising nationalistic conservatism for resources development and international frictions over iron and steel trade.

The exports of technical know-how and guidance and international cooperation from 1960 to recent years were directed mostly to developing nations in the form of technical training, operational guidance and construction consultancy of iron and steel plants, but many of these were small in scale. Since the latter half of the 1970's, however, significant changes in the technical cooperation have begun to appear. Today, the cooperation is extended to industrialized nations, too, and requests for participation of Japanese firms in large scale projects are increasing year by year. As shown in Table 5, the forms of technology exports of the Japanese iron and steel industry in 1980 have widely varying forms such as simple licensing, feasibility study, engineering, operational guidance, consultancy, etc. including many large projects.

Presently the world iron and steel industry is facing many problems such as frictions among advanced nations over trade due to the stagnant market condition, the weakening international competitiveness of the United States' industry and those in the European Community on one hand and rapidly increasing production capacity in the industries of developing nations on the other hand. It has become necessary for the Japanese industry to carefully examine and review this situation and the future trend of the world iron and steel industry.

\section{Material Saving, Energy Saving and Less Dependence on Oil}

Nearly $15 \%$ of the gross oil consumption of Japan is by the iron and steel industry. Being the largest energy consumer, the iron and steel industry has been making continuing strenuous efforts for research and development of heat economy technology. Each firm intensified such efforts since 1973 when the nationwide concern over energy supply rose following the Oil Crisis.

Looking at the 1979 energy consumption of the industry, it is shown in terms of the actual heat value that the total consumption was 564 trillion kcal (by oil equivalent, approximately 62.63 million $\mathrm{k} l$ of which $65 \%$ was coal and its derivatives, $14 \%$ petroleum products $(13.8 \%$ for oil and $0.4 \%$ for LNG) and $21 \%$ purchased electricity. Comparing with the pattern of 1978 when $61 \%$ was the coal derived energy, $21 \%$ oil and 18\% electricity, one can notice a significant decrease in oil consumption. (In the above statistics, by-product gases of iron and steel works sent to the cooperative power stations (joint venture of a steel company and an utilities company) is included in the coal consumption and deducted from the consumption of electricity.) Integrated iron and steel firms consumed 469 trillion kcal (approximately 52.07 million $\mathrm{k} l$ by oil equivalent) or $83 \%$, while the independent electric furnace operating firms of ordinary steel, special steel, and ferroalloy makers, independent roll- 
Table 5. Records of technology exports (November 1, 1979 October 31, 1980).

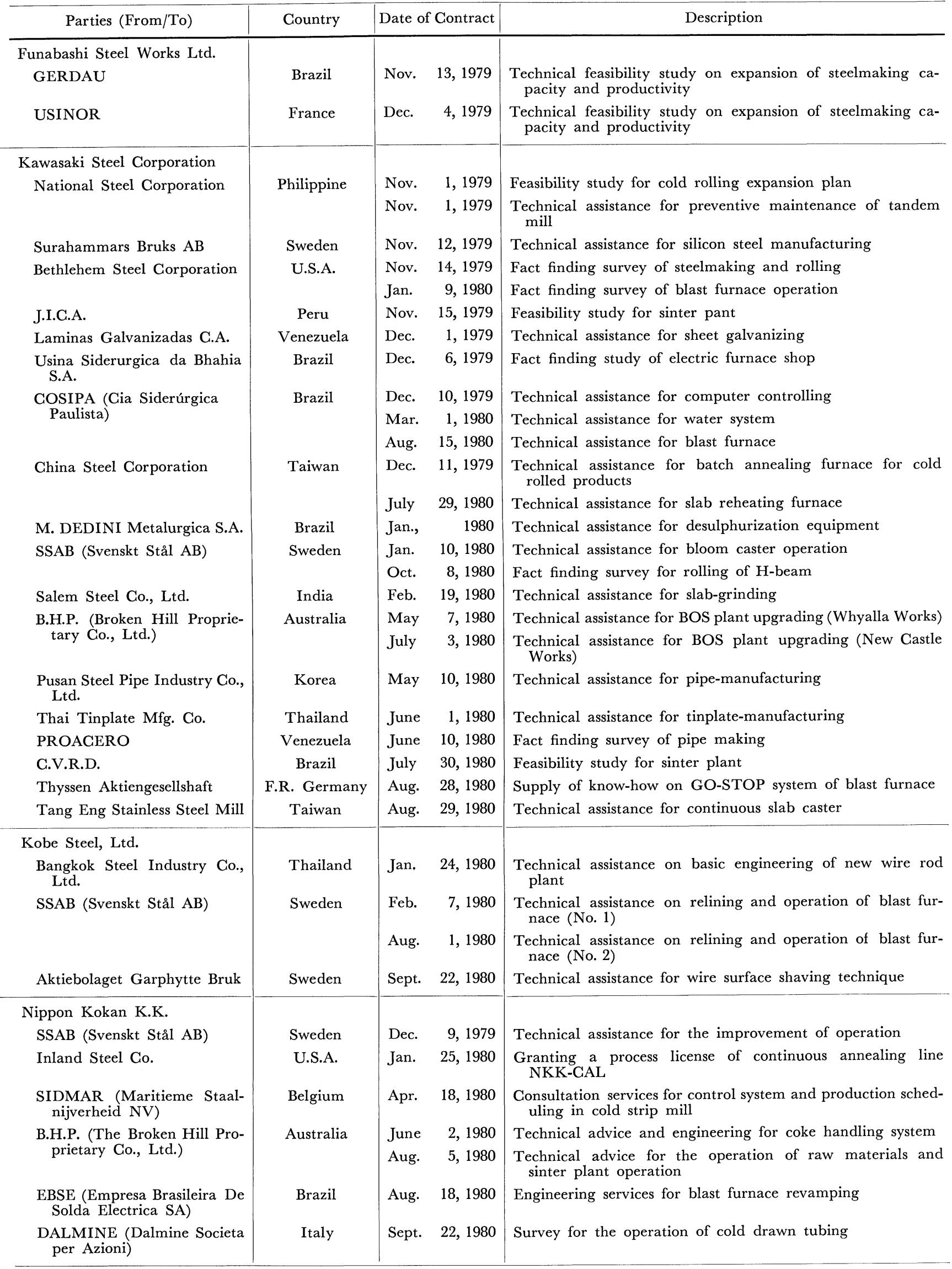


Table 5. Continued.

\begin{tabular}{|c|c|c|c|c|}
\hline Parties (From/To) & Country & \multicolumn{2}{|c|}{ Date of Contract } & Description \\
\hline $\begin{array}{l}\text { Nippon Metal Industry Co., } \\
\text { Ltd. } \\
\text { Ilssa Viola }\end{array}$ & Italy & Nov. & 2,1979 & $\begin{array}{l}\text { Technical assistance for the operation of hot rolling by } \\
\text { Steckel Mill }\end{array}$ \\
\hline \multirow{2}{*}{$\begin{array}{l}\text { Nippon Steel Corporation } \\
\text { B.H.P. (The Broken Hill Pro- } \\
\text { prietary Co., Ltd.) }\end{array}$} & \multirow[b]{2}{*}{ Australia } & & & \\
\hline & & $\begin{array}{l}\text { Nov., } \\
\text { Mar., }\end{array}$ & $\begin{array}{l}1979 \\
1980\end{array}$ & $\begin{array}{l}\text { Operation assistance for Port Kembla Works No. } 5 \mathrm{BF} \\
\text { Engineering and commissioning of Torpedo desulfurization } \\
\text { System }\end{array}$ \\
\hline $\begin{array}{l}\text { SOMISA (Sociedad Mixtra } \\
\text { Siderurgia Argentina) }\end{array}$ & Argentina & Dec., & 1979 & $\begin{array}{l}\text { Technical assistance II for operation and maintenance in } \\
\text { ironmaking area }\end{array}$ \\
\hline $\begin{array}{l}\text { C.S.N. (Companhia } \\
\text { Siderúrgica Nacional) }\end{array}$ & Brazil & Jan., & 1980 & Start-up assistance of No. 3 BOF \\
\hline $\begin{array}{l}\text { SNS (Société Nationale de } \\
\text { Sidérurgie) }\end{array}$ & Algeria & Jan., & 1980 & Start-up assistance of OG in No. 1 Steelmaking Shop \\
\hline $\begin{array}{l}\text { SOLMER (Société Lorraine et } \\
\text { Méridionale de Laminage } \\
\text { Continu) }\end{array}$ & France & Feb., & 1980 & License for sub-lance and dynamic control of $\mathrm{BOF}$ \\
\hline \multirow[t]{2}{*}{ Algoma Steel Corporation } & \multirow[t]{2}{*}{ Canada } & Mar., & 1980 & License for sub-lance and dynamic control of $\mathrm{BOF}$ \\
\hline & & July, & 1980 & Engineering services for the relining of the blast furnace \\
\hline ITALSIDER (Italsider S.p.A) & Italy & Apr., & 1980 & Technical cooperation agreement-IV \\
\hline Piombino & Italy & Apr., & 1980 & Technical cooperation agreement-II \\
\hline HAMERSLEY & Australia & Apr., & 1980 & Feasibility study for direct reduction plant \\
\hline TUBACERO & Mexico & June, & 1980 & Technical assistance for ERW mill \\
\hline USIMINAS & Brazil & July, & 1980 & License for sub-lance and dynamic control of $\mathrm{BOF}$ \\
\hline $\begin{array}{l}\text { ENSIDESA (Empresa Nacio- } \\
\text { nal Siderúrgica, S.A.) }\end{array}$ & Spain & July, & 1980 & Technical cooperation for ironmaking area \\
\hline SSAB (Svenskt Stål AB) & Sweden & July, & 1980 & General consultation-II \\
\hline $\begin{array}{l}\text { SICARTSA (Siderúrgica Lá- } \\
\text { zaro Gárdenas-Las Truchas, } \\
\text { S.A.) }\end{array}$ & Mexico & Sept., & 1980 & Basic engineering for plant mill \\
\hline \multicolumn{5}{|l|}{ Sumitomo Metal Industries, Ltd. } \\
\hline $\begin{array}{l}\text { United States Steel Corpora- } \\
\text { tion }\end{array}$ & U.S.A. & Jan. & 19,1980 & $\begin{array}{l}\text { Technical assistance for steel making, plate rolling and pipe } \\
\text { manufacturing }\end{array}$ \\
\hline Gonduven C.A. & Venezuela & Mar. & 13,1980 & Technical assistance for ERW pipe manufacturing \\
\hline$\underset{\text { Paulista })}{\text { COSIPA }}$ (Gia Siderúrgica & Brazil & $\begin{array}{l}\text { Apr. } \\
\text { Oct. }\end{array}$ & $\begin{array}{r}4,1980 \\
14,1980\end{array}$ & $\begin{array}{l}\text { Training services of production control } \\
\text { Training services for operation of hot strip mill }\end{array}$ \\
\hline KISCO & Korea & May & 12,1980 & Technical assistance for extrusion mill \\
\hline TEKSID & Italy & July & 10,1980 & $\begin{array}{l}\text { Technical assistance for improvement of the front axle pro- } \\
\text { duction line }\end{array}$ \\
\hline $\begin{array}{l}\text { ISGOR (South African Iron } \\
\& \text { Steel Industrial Corp. } \\
\text { Ltd.) }\end{array}$ & South Africa & Aug. & 1,1980 & $\begin{array}{l}\text { Engineering on utilization of non-coking coal for partial } \\
\text { briquette blending process }\end{array}$ \\
\hline \multicolumn{5}{|l|}{$\begin{array}{l}\text { Tokyo Steel Manufacturing Co., } \\
\text { Ltd. }\end{array}$} \\
\hline TAMCO & U.S.A. & Jan. & 21,1980 & $\begin{array}{l}\text { Technical assistance for operation of steelmaking and con- } \\
\text { tinuous caster }\end{array}$ \\
\hline
\end{tabular}

ers, steel forging mills and steel foundaries all combined used the remaining 17\%, 95 trillion kcal (10.56 million $\mathrm{k} l$ by oil equivalent). $76 \%$ of the consumption of integrated works is coal and its derivatives, including COG, BFG and LDG, the percentage of petroleum fuels being only $12 \%$. On the other hand, the other manufacturers depend mainly on purchased electricity representing $68 \%, 24 \%$ on petroleum fuels principally for reheating furnaces.

The consumption of oil in 1979 decreased to 8.7 million $\mathrm{k} l$ from 15.45 million $\mathrm{k} l$ in 1978 . The consumption during the April to June quarter of 1980 is estimated at 1.68 million $\mathrm{k} l$ (6.7 million $\mathrm{k} l$ on an annual basis) which means an annual $44 \%$ cutdown from 1979 and $56 \%$ from the same quarter of 1979. In terms of the per MT of crude steel the consumption was $77 l$ in 1979 and $58 l$ in the April to June quarter of 1980 , a decrease by $40 \%$ and $55 \%$ respectively from $129 l$ of 1978 .

Thus, the saving efforts not only of oil, but also of other kinds of energy of the iron and steel industry has been quite effective: assuming that energy consumption per MT of crude steel in 1973 was 100, that of 1980 was 90.5 (as shown in Fig. 2).

Among the processes, sintering, cokemaking, ironmaking, steelmaking and rolling require large energy supply. Various measures taken for energy saving in each field are discussed below. 


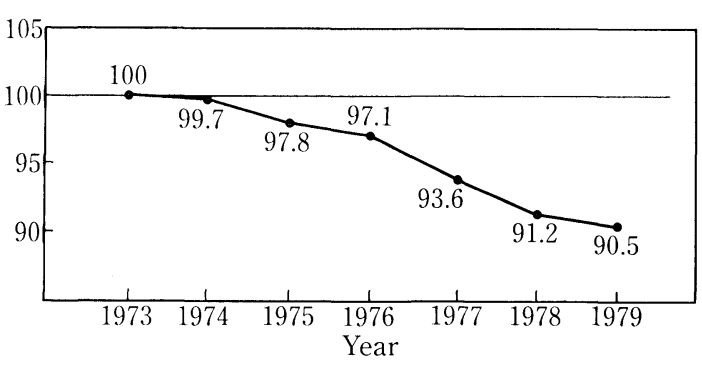

Fig. 2. Yearly change of real energy consumption per ton of crude steel (1973 consumption $=100)$.

Energy saving measures in the coking and sintering processes include combustion control of coke ovens and sintering furnaces, coke dry quenching (CDQ), recovery of waste heat from sinter coolers and recovery of radiant heat from sintered ore. The CDQ is a technique to recover the sensible heat of coke as steam by cooling the red-hot coke of $1000^{\circ} \mathrm{C}$ with inert gas which acts as heat transmitter. The GDQ facilities have been installed at Ohgishima Plant of Keihin Works, Nippon Kokan K.K. and Chiba Works, Kawasake Steel Corp. and others.

A very effective energy saving measure in sintering process was put into practice first in Japan. Namely, the system for No. 5 sintering machine of Fukuyama Works, Nippon Kokan K.K. coming in operation in 1980 is capable of treating 600000 to $700000 \mathrm{Nm}^{3} /$ $\mathrm{hr}$ of cooler waste gas $\left(300^{\circ} \sim 350^{\circ} \mathrm{C}\right)$ to recover the heat as steam $\left(230^{\circ} \mathrm{C}, 13 \mathrm{~kg} / \mathrm{cm}^{2}\right)$ and to pre-heat combustion air of the ignition furnace.

In ironmaking, about $50 \%$ of the total energy consumption in a steel works is for blast furnaces. Since reduction of fuel ratio is very effective energy saving, much attention has been paid to this aspect as discussed in Section II. 1. Other measures taken to recover waste energy include recovery of high pressure energy using BF top pressure recovery turbine, recovery of waste heat in stave cooling, recovery of waste heat from hot stoves and recovery of radiant heat from BF slag.

Number of BF top pressure turbine generators in Japan was 24 as of July 1980, which included two new facilities installed by Nippon Steel Corp., one for the No. 1 BF of Oita Works $(11000 \mathrm{~kW}$, Sofraire type, constructed in February) while the other (15 $000 \mathrm{~kW}$, Sofraire type, constructed in July) for the No. 1 BF of Nagoya Works.

The hot stove waste heat recovery facilities were installed at No. 1 and No. 3 BF of Kashima Steel Works, Sumitomo Metal Industries, Ltd. and No. 5 BF of Fukuyama Works, Nippon Kokan K.K. Kawasaki Steel Corp. started construction of BF slag radiant heat recovery plant of capacity of $40 \mathrm{t}$ of slag/hr at Chiba Works. This plant was developed jointly with Kawasaki Heavy Industries, Ltd. on an experimental basis and would be used commercially.

In the field of steelmaking, energy saving is effected by improvement of converter gas recovery and continuous casting ratio. Although the quantity of generated converter gas fluctuates greatly, taking into account that it is a pollution free fuel all people con- cerned are quite intent on its effective utilization. The rate of recovery increased nearly 3 times as much from $25.2 \mathrm{Nm}^{3} / \mathrm{MT}$ of crude steel in 1973 to 73.1 $\mathrm{Nm}^{3}$ in 1979.

In the past the heat discharged from converter slag was not utilized at all but studies have been made lately on the possible recovery of radiant heat of the converter slag. Nippon Kokan K.K. completed a three year (since July 1977) experiment at a $20 \mathrm{t}$ of slag/hr test plant in the No. 3 Steel Shop of Fukuyama Works and is operating now the world's first comprehensive converter slag treating system. This system, which is expected to be put into industrial application in the summer of 1981, consists of treating molten converter slag with high speed air and recovering the waste heat as steam and at the same time producing spherical slag products with a diameter of $3 \mathrm{~mm}$ or less.

In the rolling field, energy saving measures include improvement of heat pattern in reheating furnaces with a modified design if necessary, intensification of furnace body insulation including double insulation for skids, automation of air-to-fuel ratio control, waste heat recovery at the soaking pit, hot charging of slab and direct rolling. Among the above-mentioned measures the direct rolling, in which slabs or blooms are fed directly to the hot rolling mill, eliminating cooling process for defect removal and reheating process, is quite effective to reduce the fuel consumption. Sumitomo Metal Industries, Ltd. has been operating 3 types of hot charge rolling for the purpose of expanding the capacity of hot rolling (direct rolling, hot charge of C.C. semi-products and hot charge of conventional slabs). In July 1980, the hot rolling mills of Kashima Steel Works established the best hot charge rolling record of $180000 \mathrm{MT}, 52.7 \%$ of the total monthly rolling. The firm has also developed an optical hot defect detector for continuously cast slabs presumably for the first time in the world. This apparatus was installed on No. 1 continuous casting machine of Kashima Steel Works and has been showing good results.

The continuous annealing process, which offers advantages such as shorter annealing time, better uniformity in quality and superior shape in comparison with the conventional batch process for black plates and cold-rolled strips, has been widely used. In 1980 Kawasaki Steel Corp. constructed and started operation of a newly developed multi-purpose annealing line that is able to treat high strength steels, magnetic sheets and others at its Chiba Works. Nippon Kokan K.K., on the other hand, has developed and operated a continuous tunnel type annealing system by remodeling the conventional batch type annealing facilities.

As described in the foregoing, the Japanese iron and steel industry, has been successful up to now in energy saving efforts mainly directed to the control of the better usage of energy and the modification of existing production processes. However, such efforts cannot proceed forever. From now on attention should be paid to other energy saving measures, 
the kinds which will require a considerable time for development and may turn out to be not much effective from the investment standpoint. Thus, it seems to be the industry's sacred mission that the industry will have to spend a large amount of money for development and application of new energy saving techniques.

Besides energy saving, the iron and steel firms should endeavor to use more extensively coal and its derivatives, especially low grade coal. Experiments are presently being carried out by some of them to develop gasification and liquefaction of coal. In this connection, the development of equipment technology and operational technology as well as coal procurement methods including the ways and means of securing a steady supply of coal will become one of the central themes of the coming years.

\section{Environment Protection}

The iron and steel industry, being a consumer of a great deal of materials and fuel, has been paying special attention on environmental protection. The industry as a whole has put in practice comprehensive pollution prevention programs by establishing several committees charged with specific tasks within The Japan Iron and Steel Federation.

With the enactment of the Basic Law on Pollution Prevention Measures in 1967, Plant Location Committee and Pollution Committee were organized in August 1967, and then, Industrial Waste Materials Disposal Committee in 1971. Committee for JIS Standardization of BF Slag was also organized in 1972. Further, as the public began to show more concern over the hazards of $\mathrm{NO}_{x}$ such as smog, Committee for Technological Development for Abatement and Removal of $\mathrm{NO}_{x}$ in Iron and Steel Industry was added in August 1973. At the same time the Technological Research Fund and the Technological Research Association specifically focussed for abatement and removal of $\mathrm{NO}_{x}$ in the steel industry were established. The Fund, since its establishment in September 1973, has extended financial research aid on five occasions to environmental equipment manufactures, universities and other institutes. The researches include the developmental works such as low $\mathrm{NO}_{x}$ burner, studies on $\mathrm{NO}_{x}$ generation mechanism and measuring techniques. The total amount of such aids to 69 research items exceeded 1.4 billion yen. Reorganizing the need of furthering environmental researches not only to $\mathrm{NO}_{x}$, but also to other pollutions, the Fund was redesignated as The Fund for Development of Environment Protection Technology in Iron and Steel Industry in January 1980 for the purpose of enlargement of the Fund coverage.

The Research Association formed by integrated iron and steel makers have been conducting three major studies, namely, "Selective Contact Reduction Method", "Electron Beam Irradiation Method" and "Technology to Reduce Nitrogen in Coke for Sintering". As for the first item the Association started in December 1974 and completed in May 1977 operations of a test plant with a treating capac- ity of $5000 \mathrm{Nm}^{3} / \mathrm{hr}$. As for the second a test plant was operated from July 1977 to June 1978. Similarly experiments were carried out for the third from July 1975 to May 1978. Thereafter, the Association conducted research on a new theme "Test on Sintering Gas with Low Temperature Denitrification Catalyst". The Japanese Government extended a subsidy (amounting to 425.05 million yen) for the abovementioned researches relating to $\mathrm{NO}_{x}$. Having accomplished initial objectives the Association was liquidated at the end of March 1980. Major industries in Japan including the iron and steel industry jointly carried out a large scale survey including field surveys for development of generally adoptable techniques of $\mathrm{NO}_{x}$ pollution assessment for two years from 1975.

Each iron and steel firm, on the other hand, has also carried out development of effective pollution prevention technology and made extensive investment on prevention of air pollution, water contamination and solid waste disposal. In the field of air pollution, attentions have been paid to counter- $\mathrm{SO}_{x}$ measures such as reduction of sulfur content in fuel, desulfurization of coke oven gas and some works installed large size exhaust gas denitrification equipment of sintering plants where their local situations necessitated it. As a result, in 1979 approximately $90 \%$ of total areas in Japan met the official environment standard relating to $\mathrm{SO}_{x}$. It will not be long before the standard is satisfactorily met throughout the country.

As for the $\mathrm{NO}_{x}$, the statutory nation-wide environment standard of May 1973, which set a very strict level for $\mathrm{NO}_{2}$ to be $0.02 \mathrm{ppm}$ or less per hour average day-the strictest in the world-, came into force in August 1973 and was revised to a stricter level in December 1975 and June 1977 successively. However, it was mitigated in July 1978 to the range of 0.04 to $0.06 \mathrm{ppm}$ or less per average day taking into account then existing scientific findings. At the same time the applicable areas were classified into three, that exceeding the standard, that falling under the standard and that below the standard so that appropriate measures could be taken, respectively. In July 1979 the standard on discharge was revised in order to cover wide range of facilities for heating purposes. The iron and steel industry, in order to meet these national and local environment regulations, has been trying to use low pollution fuels, low $\mathrm{NO}_{x}$ burners and waste gas recycling methods and others relating to combustion.

In connection with water contamination, the Water Contamination Prevention Law was promulgated in 1970 providing the nation-wide discharge standard on cadomium, PCB, sexivalent chromium, mercury and others which give hazardous effects on human health as well as pH, COD, SS, fat, copper, zinc and others which give detrimental effects on living environment. Further, the Law provided provincial governments with the authority of setting stricter regulations. Particularly for the Setonaikai (the Inland Sea), because of its important location and peculiar geo- 
graphical features, various regulations have been put in force under the Temporary Measures Law for Environment Protection of the Setonaikai. As it was found that pollutant density regulations alone could not make effective control of water contamination, in 1978 the Government revised the Water Contamination Prevention Law by introducing gross COD regulations to Tokyo Bay, Ise Bay and the Setonaikai together with amendments of Temporary Measures Law relating to the Setonaikai. As a result COD gross volume regulations came applicable to the above-mentioned three semi-closed waters from June 1979 and directions to reduce phosphorous (nutrition to microbes detrimental to fishery) in the Setonaikai were announced.

The iron and steel industry's efforts in this field have been mainly directed for strengthening recirculation rate of industrial water to minimize outside discharge and resulted in a near $100 \%$ at all modern works.

The iron and steel firms are also concerned with noise, vibration and bad odor problems and making efforts to find countermeasures applicable from the cost standpoint.

There has been significant advancement in the field of slag utilization technology. Blast furnace slag has been used as road materials for a long time, and this accounts for approximately $50 \%$ of the total usage. The slag used as coarse aggregates for concrete was standardized as a JIS standard, JIS A 5011 in 1978. $\mathrm{BF}$ sand slag by water cooling has been used as cement making ingredient for a long time, but its amount is insignificant. In order to encourage the utilization of slag in this field, researches are conducted on the mixing of BF slag in general purpose portland cement.

In June 1980, the Committee for Utilization of Slag of the Japan Iron and Steel Federation compiled " Research Report on Standardization of Slag Aggregates for Concrete" which shows that the BF slag aggregates can be effectively used and that in $197895 \%$ of BF slag was reutilized as resources.

Converter slag, having superior wear resistance, has been used as asphalt aggregates in Japan as in many other countries. As the converter slag contains a considerable amount of metallic iron, it is recovered in magnetic separation process after pulverizing. In 1978,30 to $40 \%$ of converter slag was someway or others reutilized as resources. As an example of utilization of converter slag, Keihin Works of Nippon Kokan K.K. is employing a thorough recycling system for all wastes in order to overcome difficulties associated with their plant location. The current recycling rate is as high as $98 \%$. However, as a whole some difficult problems relating to this slag disposal are remaining still to be solved.

As reported above, the Japanese iron and steel industry is trying hard to establish itself as a clean industry. Their serious efforts much contributed to rapidly improving environment in Japan. The industry will be increasingly involved in world-wide activities in the future while the latent shortage of min- eral resources and energy sources will become more apparent. Under these circumstances the Japanese iron and steel industry is in the position to strengthen comprehensive environment protection under closer relations with advanced as well as developing and resources producing nations.

\section{Activities of Various Research Societies}

\section{Joint Research Society}

The Joint Research Society is conducting joint researches on iron and steel manufacturing technology with its 18 committees and 23 subcommittees. Various research reports, discussions and technical information presented or exchanged through their activities have been very valuable.

\section{Ironmaking Committee}

The 55th meeting of the Ironmaking Committee featured two keynote lectures, "High Rate Operation of Ironmaking Facilities of Nakayama Steel Works, Ltd." (by that company) and "Construction and Operation of Qatar Steel " (by Kobe Steel, Ltd.). The meeting discussed on "Problems in Ironmaking Arising from Changes in Energy Supply", while 9 papers were presented on other subjects.

In the 56th meeting, 2 keynote lectures were presented on "Elongation of Blast Furnace Life" (by NSG) and "Experiment with a Large Burden Distributor of Blast Furnace and Its Comparison with Actual Performance" (by NKK). "Quality Control of Hot Metal" was selected as the common study theme.

\section{Coke Committee}

The Coke Committee in its 20th meeting featured a keynote lecture on "Interm Report of the Committee on Basic Properties of Coal" (presented by Mr. Hideo Kimura, Subcommittee Chairman) and discussed on the three common themes, "Present Problems and Future Prospects of Quality Control of Coke ", "Present Problems and Future Prospects of Combustion Control of Ovens" and "Maintenance Problems of Coke Gas Refining Facilities". In addition, 4 reports were presented on other subjects.

The 21st meeting featured a keynote lecture on " Mechanism of Coal Carbonization for Blast Furnace Cokemaking " (by Assit. Prof. Isao Mochida, Research Institute of Industrial Science, Kyushu Univ.) and discussed on common themes of "Present Problems and Future Prospects of Coke Properties and Coke Oven Operation", "Recent Environment Improvements in Coke Plants" and "Energy Saving Measures at Coke Plants". 4 papers were presented on other subjects.

\section{Steelmaking Committee}

The committee held three meetings in 1980 to discuss " Raising of Continuously Cast Steel Ratio by Improvement of Productivity and Sequential Continuous Casting Technology " in the spring, "Utilization of Secondary Refining for Decrease of Impurities and Inclusions" in the summer, and "Raising of Continuously Cast Steel Ratio with Improvement of Internal Quality" in the fall. 


\section{Electric Furnace Committee}

Passing one year since the reorganization of this committee, the new Electric Furnace Committee conducted vigorous activities. In the 15 th meeting, continuing the studies of the previous year, two subjects, "Improvement of Melting Capacity of Electric Furnace" and "Energy Saving Measures at the Steelmaking Shop" were discussed in the depth. A keynote lecture titled "Preheating of Scrap Using Waste Heat" was presented by Mr. Shozo Yasukawa of Nikko Co., giving valuable ideas on the scrap preheating.

The 16th meeting discussed on various measures each plant was adopting on " Energy Saving in Electric Furnace Operation" and "Quality Improvement". In addition to the above-mentioned activities, a subcommittee was established in 1980 to compile the data on the present state of improvement of melting efficiency of electric furnace, the subject discussed in the previous 4 meetings. The Subcommittee is working still on this task. It should be mentioned here that the Special Research Team on Electric Furnace of the International Iron and Steel Institute (IISI) visited various Japanese firms for 2 weeks from November 10.

\section{Special Steel Committee}

The Committee agreed to hold three meeting each year starting in 1980. The 61st meeting studied the common themes "Improvement of Internal Quality Inclusions and Defects of Low Alloy Steels by Improving the Steelmaking Process" and "Improvement of Internal Quality of Stainless Steels". Six firms presented papers on each subject for discussion.

In the 62nd meeting the Committee discussed on the technology relating to forging under the themes of "Improvement of Quality and Yield of Forged Products" and "Rolling without Surface Conditioning by Improved Steelmaking ", which has not been discussed for some years.

The 63rd meeting studied the subjects to be discussed once a year, namely, " Electric Furnace Operation Related to Rapid Melting, Energy Saving, and Resources Saving " and "Improvement of Secondary Refining Technology for Low Alloy Steels and Special Steels". In connection with the electric furnace operations 6 firms presented papers on preheating of scrap and energy saving aimed at rapid melting of EF-AOD stainless steel making.

The three keynote lectures, the first titled "Manufacturing of Special Steels at Yawata Works" (by Mr. Tomokatsu Kohtani, NSC) for the 61st meeting, and the second, "Manufacturing of Special Steels at Muroran Works" (by Mr. Shujiro Ono, NSC) for the 62nd meeting, and the third, "Operations and Their Characteristics at Sendai Works of Azuma Steel Co., Ltd." (by Dr. Hidetaro Nemoto, Azuma Steel Co., Ltd.) for the 63rd meeting were made.

\section{Steel Plates and Sheets Committee}

This Committee consists of the Subcommittees of Blooming and Slabbing, Plate, Hot Strip and Cold Strip.
The meetings of the Blooming and Slabbing Subcommittee are held twice annually to present papers for discussion in the Blooming Group and in the Slabbing Group. The Subcommittee selected, as the common research theme, "State of and Measures for Breakdown of Continuously Cast Bloom" (Blooming Group) and " Reduction of Fuel Consumption at Soaking Pit" (Slabbing Group) in the 50th meeting, and "Introduction of CPU System" (Blooming Group) and "Direct Rolling and Hot Charging" (Slabbing Group) in the 51st meeting.

The Plate Subcommittee also meets twice a year and studies subjects of common concern separately by the Staff Group and the Foremen Group. The Staff Group studied " Rolls" and " Cost Reduction Measures in the Quality Assurance" at the 49th meeting, and "Problems in and Measures for Quality Improvement with Regard to Preceding Processes" at the 50th meeting, in which the Subcommittee invited former members and featured a few keynote lectures as the commemoration of the 50th meeting.

The Hot Strip Subcommittee held two meetings in 1980. Active discussions were conducted on "Yield in Rolling and Final Finishing " at the 32nd meeting and "Improvement of Unit Consumption of Roll Cost" at the 33rd meeting.

The Cold Strip Subcommittee meets twice a year also. Each meeting in 1980 had participants exceeding 140 in number, and papers on recent achievements of each firm were presented in 2 sessions. The 31st meeting selected "Survey of Present Manning and Labor Saving at Cold Rolling Mill" as the discussion theme, while the 32nd meeting studied " Practical Examples of Quality Control and Quality Improvement" over entire processes from pickling to final finishing.

\section{Sections and Wire Rods Committee}

The Committee is subdivided into the Subcommittees of Large Sections, Medium and Small Sections, and Wire Rods. Each subcommittee meets twice a year to present plant operation state reports and to discuss one or two common research themes.

The Large Sections Subcommittee studied "Yield Improvement Measures in Rolling " at the 31st meeting and "Current State of and Porblems in Shape Correction" at the 32nd meeting. A keynote lecture titled "Photo-elasticity Stress Analysis of Caliber Rolls" was made at the 31 st meeting.

The Medium and Small Sections Subcommittee examined "Energy Saving Measures" and "Bundling and Marking of Products" at the 48th meeting and "Manning Rationalization" at the 49th meeting. At the 48th meeting a keynote lecture was made on "New Installation and Remodeling of Medium and Small Sections Rolling Mills".

The Wire Rods Subcommittee examined " Current State of and Measures for Energy Saving" at the 49th meeting and "Current State of and Measures for Improving Yield " at the 50th meeting.

\section{Steel Pipes and Tubes Committee}

The Committee held two annual meetings, and both the Seamless Pipe Subcommittee and the Welded 
Pipe Subcommittee also met twice a year.

The Committee generally takes up subjects for discussion common to all participants relating to pipe manufacturing. At the 34th meeting the Committee studied "Prospects of Pipe Manufacturing Technology in Coming 5 Years" and "Control and Maintenance of Facilities" as well as "Current State and Prospects of Pipe Manufacturing Technology", the last in the panel discussion form at the 35th meeting. In addition, 3 papers were presented on other unspecified subjects at each of the meetings. The 34th meeting featured a keynote lecture on "Outline of 26 inch Electric Seam Welding Pipe Manufacturing Line of Chita Works, Kawasaki Steel Corp.".

The Seamless Pipe Subcommittee at the 26th meeting received papers on "Quality and Cost Reduction of Billets for Extrusion" and "Cold Processing Tools" in the field of hot extrusion and "Sizing Accuracy" and "Rolling Schedule for Tube Rounds" in the field of Mannesmann process. At the 27th meeting the Subcommittee received papers on the common theme of "Energy Saving" and "Operation Control of Major Facilities" as an optional subject in the field of hot extrusion, and in the field of Mannesmann process on the common theme, "Technology for Pipe Manufacturing Tools" and an optional theme, "Energy Saving ".

The Welded Pipe Subcommittee studied "Effects of Butt-welding Conditions on Welded Seam Strength" and "Energy Saving" in the field of buttwelded pipes, "Yield and Line Utilization Rate", "Quality and Quality Assurance System for Welded Joints" in the field of electric welded pipe, "Appearance, Shape and Size of Pipe" and "Quality of Welded Joints" in the field of straight seam welded pipes and "Manufacturing Efficiency" and "Quality of Welded Joints" in the field of spiral pipes.

At each subcommittee meeting member firms reported their plant operation performance reports, too.

\section{Rolling Theory Committee}

In this Committee the members are composed of iron and steel manufacturers, rolling facilities and electric instruments manufacturers and researchers of universities. The meetings were held in March, June and November to receive research papers on rolling of plates, wire rods, and pipes. The Cold Rolling Lubrication Subcommittee conducted a joint research on rolling lubrication at the two meetings.

\section{Heat Economy Technology Committee}

The Committee holds two annual meetings. At the 66th meeting data were collected on the common survey theme of "Overall Listing of Energy Saving Facilities" and "Heat Balance and Energy Saving Measures at Steelmelting Shop". A research paper of " Energy Saving Activities at Kure Works of Nisshin Steel Co., Ltd." and 22 other papers on unspecified subjects were presented. The 67 th meeting received studies on "Current State of and Problems in the Furnace Body Insulation for Furnace" and the final survey report of the Energy Saving Research Subcommittee, and compilations of energy balance data contributed by all the member firms on 1979 per- formances was adopted. 28 papers on unspecified subjects were also presented. The Energy Saving Facilities List presented at the 66th meeting covers the results of comprehensive investigation on facilities installed during the 6 years from 1974. It must be noted here the Committee decided that this kind of data compilation should be carried out every year.

\section{Refractory Materials Committee}

The Committee meets twice each year. At the 27th meeting, reports were presented on "Materials for Tapping Floor of Blast Furnace" and at the 28th meeting reports on "Refractories for Ladle" were presented. The Committee has been compiling data on consumption of refractories at each member firm twice a year.

\section{Instrumentation Committee}

One hundred and thirty-two participants received 30 papers on unspecified subjects at the 74th meeting and at the 75th meeting 147 participants discussed on 36 papers with a feature lecture on "Basic Structure of Optical Measuring and Controlling System ". 31 papers on unspecified subjects were presented at the 76th meeting.

\section{Quality Control Committee}

The 42nd meeting of the Committee with the presence of 92 members received 8 papers on the common research theme, "Quality Control of Semifinished Products for Sales ", 5 papers on an optional subject, "Quality Control of Products of Special Importance ", and 4 papers on another optional subject, "Control and Assurance of Quality under Energy Saving Operations ".

The 43rd meeting received 12 papers on the common theme "Current Practices and Problems in Quality Guarantee Auditing System ". 5 papers were presented and a panel discussion was conducted on another common theme, "Corporate Standardization".

The Mechanical Tests Subcommittee held the 22nd, 23rd and 24th meetings in 1980. Discussions were conducted by dividing the participants into three sessions, namely, Automation, Standardization and Inspection System. The Working Group on Uniform Elongation completed their planned activities in 1980, and a newly created working group on Effects of Impact Blade Shape started its activities.

The Non-destructive Inspection Subcommittee held the 7th, 8th and 9th meetings to discuss on "Organizational System of NDI", "Automatic Instruments" and other subjects. Its Working Groups, namely, WG 4 (on education), WG 6 (on examination of UST test piece for heavy plates), WG 7 (on examination of possible inclusion of SAW Pipe UST into JIS Standards) and WG 8 (on examination of ASME NDE) carried respective research activities.

\section{Transportation Committee}

The Committee meets once a year to discuss the studies conducted by the subcommittees during the preceding year. The 5th meeting discussed on the common themes of "Current State and Rationalization of the Coastal Transportation" and "Current State of Systematizing Materials Flow", and received 13 
papers on unspecified subjects.

\section{Investigation Committee}

The Committee has been carrying out studies to clarify "Technological Competitiveness and Future Prospect of Technological Development in the Iron and Steel Industry". Practical activities of the Committee are conducted on four stages of "Analysis of Currents State of Technological Strength of the Japanese Iron and Steel Industry", "Future Prospects of Technological Strength of the Japanese Iron and Steel Industry", "International Comparison of Japanese Technology" and "Future of the Japanese Iron and Steel Industry in the Technological Point of View". Eight working groups on Coke, Ironmaking, Steelmaking, Plates and Sheets, Wire Rods, Pipes, Special Steels, and Stainless Steels are examining each process, while the secretariat and the joint meetings of WGs are responsible to coordinate and integrate activities of individual working groups.

Currently, the Committee is making comparative analysis of technological strength of world's iron and steel industries and also studying "Direction of Technological Advancement in Each Manufacturing Process in Coming 10 Years".

\section{Iron and Steel Analysis Gommittee}

The Committee has 5 subcommittees, Chemical Analysis, Photoelectric Emission Spectroscopic Analysis, Non-metallic Inclusions Analysis, Fluorescent Xray Analysis, and Gas Analysis in Steel. The Committee itself meets twice a year, when the subcommittees hold two of their annual four meetings.

The Photoelectric Emission Spectroscopic Analysis Subcommittee at its two meetings held concurrently with the Committee meetings compiled the last report of the round robin experiment on analysis of high alloy steel and started newly the same experiment on analysis of aluminum in steel.

The Non-metallic Inclusions Analysis Subcommittee held four meetings to supervise the progress of the round robin experiment on quantitative analysis of sulfides by extraction method.

The Subcommittee on Gas Analysis in Steel held two meetings and decided on a method of investigation by questionnaire and to conduct preliminary experiment prior to the round robin experiment.

The Chemical Analysis Subcommittee met twice to examine the quantitative analysis of trace elements in high purity iron. In connection with sulfur and iron ores, the Sulfur Analysis Method Working Group and Iron Ore Analysis Working Group are making relevant studies, respectively.

The Fluorescent X-ray Analysis Subcommittee holds 4 or 5 steering meetings every year in addition to the two subcommittee meetings. At these meetings, studies are made on Fluorescent X-ray Analysis Method using Iron Ore Briquetting Method as well as on the standard samples for instrumental analysis.

\section{Plant Engineering Committee}

The Committee consists of Subcommittees, Iron and Steelmaking Plant Engineering, Rolling Mill Engineering and Electric Facilities Engineering.
Equipment and plant manufacturers are participating in the first two subcommittees.

The Iron and Steelmaking Plant Engineering Research Subcommittee makes studies separately in ironmaking and steelmaking. The 22nd meeting received "Compiled Report on Questionnaire on Maintenance of Steelmaking Facilities " and 8 reports on "Practices of and Problems in Maintenance of Rolls for Continuous Casting". The 23rd meeting heard a keynote lecture on "Situations of Iron and Steel Industry in China " (by Mr. Tokumitsu, Chairman of the Subcommittee), the reports on "Questionnaire on Top Pressure Turbine Plant" and "Maintenance Problems of Blast Furnace Slag Hydrogranulation Facilities" and 3 papers on unspecified subjects.

The Rolling Mill Engineering Subcommittee met twice and deliberated on "Problems of and Measures for Hydraulic Servo Apparatus" at its 22nd meeting and "Anti-corrosion Measures for Hot Rolling Facilities" at its 23rd meeting, while 2 lectures were made by facilities manufacturers at each meeting.

The Electric Facilities Engineering Subcommittee held two meetings has a main theme and a subtheme. The main theme of the 8th meeting was "Deterioration Diagnosis for High Voltage Cable and Diagnosis Standard " while that of the 9th meeting was " Current Practice and Future Trend of Application of Micro-computers". At each meeting 3 papers on the 3 subthemes including that based on questionnaire and 4 papers on optional themes were presented.

\section{Committee for Utilization of Nuclear Energy}

Its Patent Group met in March to deliberate on the alleged infringement by Kawasaki Steel's " Heat Transfer Conversion Device" on the patent right held by ISIJ on " Heat Transmission Method Utilizing Irradiation Device in Heat Exchanger" (Patent Specification 1977-7192, Patent No. 877552) from such aspects as (1) determination on whether the alleged infringement was real or not and the way of handling the issure, (2) in case of licensing the patent, the amount of licensing fee and payment terms, and (3) the way of handling a similar case in future. The meeting decided this issure in favor of ISIJ on the condition that the same license fee be applied to all 17 member firms of this group with their approval. These firms are participants in "Joint Research on High Temperature Heat Exchanger for Ironmaking Using Nuclear Energy" under the Joint Research Agreement concluded in June 1971. Consequently ISIJ and Kawasaki Steel Corp. concluded an agreement on licensing (Oct. 1, 1980).

2. Basic Research Association on Specific Subjects

1. Committee on Basic Physical Properties of Coals (started in August 1977)

The activities of the Committee are conducted by following groups under a chairman on a respective subject: "Structure of Component Ingredients" (Prof. Koji Ouchi and thereafter Yuzo Sanada, Hokkaido University), "Measuring of Basic Physical Properties of Coal " (Prof. Shigemori Otani, Tohoku Uni- 
versity), "Analysis of Carbonization Reaction" (Prof. Kenjiro Takeshita, Kyushu University), "Reaction Behavior of Coke" (Prof. Mitsuru Tate, The University of Tokyo) and "Mechanism of Fracture of Coke" (Prof. Saburo Yashima, Tohoku University, and thereafter Assit. Prof. Yushichi Kimura, Tokyo Institute of Technology).

In February the Committee met to collate and present an interim report, when the Executive Committee of this association approved the continuation of these research activities in 1981.

\section{Committee on Basic Research for Effective Utilization of Slag (started in April 1977)}

Although all research activities were scheduled to complete in 1980, some more subjects were found in need of research. The Committee was approved to carry over the activities for another year due to the need of further research. During 1980 the Committee held 3 meetings and 4 working group meetings.

\section{Joint Society on Iron and Steel Basic Research}

This Society is managed jointly by Japan Society for the Promotion of Sciences, The Japan Institute of Metals and ISIJ with its headquarters placed at ISIJ. The Society consists of several committees each of which carries out basic research on a specific subject in the field of iron and steel as joint works of specialists of public research institutes and private firms. In principle, the committees are obliged to complete researches in 5 years and publish reports on respective subjects. Some of the committees hold seminars and symposia open to non-committee members to exchange views with researchers in a specific field.

\section{Committee on Reaction within the Blast Furnace (started in March 1977)}

The Committee held 3 meetings in 1980. The 11 th meeting with participation of operational staff from ironmaking plants of member firms discussed on current problems for researches from the actual operation standpoint and direction of future theoretical researches.

\section{High Temperature Deformation Committee (started in March 1977)}

The Committee met 5 times in 1980 to hear interim reports on researches disclosed by each member. Their research results are to be presented at a symposium on "High Temperature Deformation and Fracture "scheduled in February 1981.

\section{Committee on Inclusion Shape Control (started in May 1979)}

In accordance with the policies determined upon establishment in 1979, the Committee has been proceeding with preparations for research and preliminary experiment. Two meetings were held to receive reports on the preparations. On the basis of literature survey and reports, all Committee members agreed on the course of future studies.

\section{Committee on Wear of Iron and Steel Products (start- ed in July 1979)}

Three meetings were held to receive research reports on "Wear of Rolling Rolls" and "Wear of
Steel by Slurry". In connection with wear of rolling roll, the Committee decided to study the evaluation method and testing method and prior to such studies to conduct investigation by questionnaire to be sent on the mill operators and the roll makers so that all the committee members will have a common background knowledges.

5. Committee on Mechanical Behavior of Steel in Continuous Casting (started in March 1980)

The newly established Committee held two meetings to receive research reports and to examine research themes for 1981 .

6. Committee on Liquid Refining Reaction (started in March 1980)

In 1980 the Committee held 2 preparatory meeting and 2 Committee meetings to adopt the following activity plan:

1) Research on desulfurization and dephosphorization reactions between slag and molten iron from view point of equilibrium theory and kinetics theory; and

2) Research on refining reactions between slag and molten iron from the process engineering view point.

Presently the Committee is reviewing reports on researches previously conducted by universities and iron and steel firms on these subjects.

\section{Other Research Committees}

\section{Standardization Committee}

The Committee is responsible for furthering industrial standardization on iron and steel and has been conducting wide-ranged activities with its 2 subcommittees and 31 working groups.

(1) ISO Iron and Steel Subcommittee

In order to help the secretariat responsibility of ISO/TC $17 / \mathrm{SG} 1$ recently assumed by Japan, the Subcommittee made preparations of the establishment of the Secretariat and the supporting system. Also as an organization delegated by the public competent office the responsibility for ISO in Japan, the Subcommittee examined ISO drafts and prepared Japanese comments for TG 17, TG 5, TG 67 and TG 164. The Subcommittee also sent 43 delegates to 22 ISO conferences to present Japanese opinions.

The Subcommittee received 454 documents from TG 17, 25 from TG 5, 1 from TG 67, 168 from $\mathrm{TG}$ 164, 648 in total and 27 documents from DIS and IS.

(2) Data Sheet Subcommittee

The High Temperature Tensile Data Sheet Working Group is continuing the compilation of data and examination of various analysis methods and computer processing methods for deducing the guarantee values for high temperature tensile strength from the compiled data.

Fracture Toughness Data Sheet Working Group compiled data on V-notch Charpy test, low temperature tensile test, deep notch test, COD bending test, double tensile test (ESSO) and NRI drop weight test on structural plates and for pressure vessel plates and is proceeding with the data analysis using computers. 


\section{(3) Consultative Subcommittee}

The Ordinary Steel Working Group prepared JIS draft adding the $80 \mathrm{~kg} / \mathrm{cm}^{2}$ class high strength steel to SM and SPV Classifications. Also the Working Group prepared draft JIS on tinfree steel and draft revisions on JIS for tinplate and black sheets.

The Special Steel Working Group prepared draft revisions on JIS for sulfur resulfurized carbon steels, cutting steel, carbon tool steels, alloy tool steels, and high speed tool steel.

The Pipe Working Group prepared revision drafts on JIS for drilling pipes, structural alloy steel pipes and structural stainless steel pipes.

The Steel Quality Test Method Working Group also prepared draft revisions on JIS for grain size test method and non-metallic inclusions test method.

The Mechanical Test Working Group is manufacturing the standard specimens for calibration of Charpy Impact Test machines in its WG 3.

(4) ISIJ Standards Subcommittee

The Subcommittee prepared technical report of "Glossary of Terms Relating to Shape-irregularity and Surface Imperfection of Steel " on billets, blooms and slabs, sections and flat bars, bars, wire rods, pipes, tubes, plates, hot-rolled sheets, cold-rolled sheets, zinc-coated sheets, prepainted zinc-coated sheets and tinplate.

\section{(5) JIS Draft Preparation Subcommittee}

(This subcommittee is a joint committee including steel users.)

The Subcomiittee prepared a draft JIS on sheet piles by separating hot-rolled sheet piles from pipe sheet piles. The Subcommittee is composed of members from universities, research institutes, iron and steel firms, fabricators and end users.

(6) Special Committee on Investigation of Compatibility

With the conclusion of GATT Standard Code, it has become necessary to coordinate domestic standards with international standards. For this purpose, Agency of Industrial Science and Technology entrusted ISIJ with an investigation on adjustment of JIS 74 on iron and steel to ISO standards. This Special Committee appointed 8 working groups to prepare a list of comparison of JIS and ISO and to evaluate the compatibility. On the basis of the investigation the Special Committee prepared and submitted to the Agency an 1100 page report.

\section{High Temperature Strength Research Committee}

The Committee is the body reorganized of the previous Creep Committee in 1980, while Subcommittees of High Temperature Creep and Fatigue Test, High Temperature Tensile Test, High Temperature Thermal Fatigue Test, Data Sheet Preparation and National Research Institute for Metals (NRIM) Greep Data Sheet Coordination Committee were transferred to the new Committee to continue their respective activities. Members of the subcommittees were reappointed also. A new subcommittee on Creep Strength Extrapolation Method was established and started investigations. The activities of the subcommittees are as follows.
(1) High Temperature Greep and Fatigue Test Subcommittee

In the 8th meeting, the Subcommittee discussed interim reports from 12 organizations on "Results of PP, CC, PC, CP Type High Temperature Low Cycle Fatigue Test", as part of joint research on "Evaluation of High Temperature Low Cycle Fatigue Life Based on Strained Region Division Method ", as continuation from previous years. The meeting also examined "Strained Region Division Test and Analysis of High Temperature Low Cycle Fatigue Test Results Using Division Test Results".

(2) High Temperature Tensile Test Subcommittee

The 7th common high temperature tensile test was conducted with participation of 14 organizations for varied temperatures (from $400^{\circ}$ to $1000^{\circ} \mathrm{C}$ ) on a standard method (C steel, Mo steel, Cr-Mo steel, $12 \mathrm{Cr}$ steel, Stainless steel and Ni- and Co-base alloys) to obtain reliable strain hardening exponent ( $n$-value) required for designing of high temperature structures by determining the change of $n$-value with rising of temperature. At the same time the test aims at finding the limit for each metal where the hardening disappears and resistance is found from strain rate. This finding in turn would clarify the limit of applicable temperature for JIS G 0567. The test results have been submitted to the manager for compilation.

(3) High Temperature Thermal Fatigue Test Subcommittee

The Subcommittee made literature survey on Incoloy, the subject selected on the basis of questionnaire made in 1979 for preparation of a joint research plan, in which 565 items of literature were compiled. Eighteen firms and one organization participated in the survey.

The Subcommittee held the 12th meeting to appoint members responsible for assembling of the reference literature and to decide a method of compilation. Subsequently 24 additional items were selected and members responsible for examination were appointed. The 13 th meeting received the said compiled data.

(4) Data Sheet Preparation Subcommittee

As a result of survey on "Number of Data on High Temperature Strength of Welded Joint", the Subcommittee found that such data were held by 5 participating members in the Committee and by 1 associated firm. The Subcommittee will decide on the way of handling such data in the coming meeting.

\section{Test Blast Furnace Committee}

The purpose of the establishment of the Committee is to cooperate in the research on ironmaking using the pilot size blast furnace owned by the Institute of Industrial Science, The University of Tokyo. In 1980 the Committee did not make any operation of the test blast furnace but concentrated in the laboratory scale experiments and in the compilation of reports on the 28th test operation of the previous year.

\section{Materials Research Committee}

The Committee selected "Fracture Toughness" 
as a new subject of research starting from 1980. The research is to be carried on for 5 years and, in the initial 2 years the members are to conduct independent studies for presentation at the Committee meetings. Five meetings are held every year with participation of researchers of structural mechanics as well as metallurgists.

\section{Committee on History of Iron and Steel Science and Technology}

The Committee consists of Working Groups of Ironmaking, Steelmaking, Materials and Education. The second has completed the assigned activities and is preparing for publication their study results. The third are compiling draft papers while the first is making studies on the history of progress of ironmaking technology with its 4 subgroups.

\section{Committee on Iron and Steel Standard Samples for Analysis}

The Committee is responsible for manufacturing and determination of analysis value of standard samples for iron and steel and their distribution. In 1980 the Committee produced 5071 samples for chemical analysis from 21 revised steel types (including 1 carbon steel, 1 pig iron, 1 for exclusively $\mathrm{G}$ in steel, 3 for exclusively $\mathrm{N}$ in steels, 6 tool steels and 6 stainless steels). The rules of the Committee were reexamined and revised extensively in 1980 since the revision of 1972. Accompanying with this the Committee invited the manufacturers of the standard samples to explain the contents of the revision. As one of commemorative activities of the 25th anniversary of the establishment, the Committee started manufacture of 3 high purity iron standard samples (with purity of $99.9 \%, 99.95 \%$ and $99.98 \%$ ) and 13 standard samples of carbide inclusions. The latter are on distribution since December 1980.

7. Joint Research Committee on High-grade Line Pipe (HLP Committee) (started in May, 1978)

Following the first full scale burst test of November 1979, the Committee carried out the second, third and fourth tests in January, March and December.

\section{Japan Pressure Vessel Research Council (JPVRG)}

\section{(1) Materials Division}

The Committee on Fatigue Crack Growth Speed Data Compilation was established in June 1980. Presently the Council consists of this new committee and the Low Temperature Materials Committee, the Hydrogen Embrittlement Committee and the NonDestructive Examination Committee. The Council sends out delegates to PVRG Meeting of U.S.A. three times a year to present their activities reports. The fruitful results and the advanced level of the activities of the Japanese Council have been highly appreciated by PVRG at each meeting.

(2) Activities of the Committees

(i) Low Temperature Materials Committee

The Committee examined application of CR materials to pressure vessels and prepared a report including a proposal by compiling the results and presented it to PVRG and API. The latter answered back that the proposal was registered as Agenda Item No. 62073 for deliberation. (ii) Hydrogen Embrittlement Committee

Research Activities are carried out by following Task Groups:

TG 1: Hydrogen Attack in Cr-Mo Steel Weldments

TG 2: Temper Embrittlement and Hydrogen Embrittlement

TG 3: Hydrogen Embrittlement of Bond between Stainless Overlay and Base Metal

The TG 2 presented an interim report at OVRG meeting of June 1980, TG 3 presented a report at the meeting of October 1980, while TG 1 is presently preparing a report to be presented at the meeting of January 1981.

(iii) Committee on Non-Destructive Examination

Two Working Groups have completed examination of a round robin test method, standards for flaw detecting devices and methods of artificially introducing welding defects in a test block and ordered out the manufacture of the test blocks. On the other hand, the Committee received 2 test blocks from U.S.A. and in September 1, 1980, started the round robin test at Muroran Works of Nippon Steel Corp.

(iv) Committee for Collection of Data on Fatigue and Crack Growth Speed

The Committee, aiming at data collection on austenitic stainless steels for BWR, PWR and FBR existing in Japan, and weld joints and steels for pressure vessels, decided to carry out following activities.

a) To carry out an enquête on time schedule for publication of data in the high temperature water among the member firms;

b) To discuss and decide on its relations with ICGGR Committee and time limit for the further data collection with Dr. Banford; and

c) To collect and compile data from Japanese sources and to adopt MPC analysis values.

\section{International Iron and Steel Technical Committee}

The 12th IISI Technical Committee was held in Brussels in June 1980 to discuss on "Coke Production" and "Energy Problems". Japanese participants presented 4 papers including one by Mr. Shinoda (NKK). The meeting decided to conduct a survey on operation data of sintering, blast furnace, converter and continuous casting.

\section{Japan Iron and Steel Technical Informa- tion Center (JISTIC)}

The Center was established in April 5, 1978 as a division of The Iron and Steel Institute of Japan specialized in information services.

It is located at 10th Floor, Nippon Building Bekkan, 7-1, Otemachi 2-chome, Chiyoda-ku, Tokyo (Tel. 03-241-1228, Postal No. 100), five minutes' walk from the Institute. Depsite the name of this center its information services cover all metals technologies. At this moment the personnel of JISTIC is 13. The outline of JISTIC's activities is given below.

\section{Library}

The inventory of the library contains about 170 Japanese journals and 70 foreign journals. Besides these it has two special book assemblies: one is numeric data assembly (app. 300 books at this moment) 
such as industrial standards and codes books, design manuals and data sheets and fundamental scientific and technical data books, the other an assembly of international convention or symposium proceedings (app. 480 proceedings at this moment). JISTIC is intent to enrich further these two assemblies as far as its finance allows. A card retrieval system for them is underway.

(1) Use of Library: Free to everybody

(2) Lending: Available only to the member of the Institute and some qualified persons without payment

(3) Reference: Receptive to documental inquiries made by visit, phone or letter without payment

(4) Copying: Xerox copying available with payment according to the set fee list in compliance with the Copying Law

\section{On-line Mechanical Retrieval Service}

JICST's special terminal equipment is placed for use of information searchers with payment according to the set fee list. (However, members of the Institute and some qualified persons can get 50\% discount) (at present app. 50 minutes of payable time/ day)

Data files accessible through the JICST Terminal are as follows: JICST, CAS, MED, TOX, SSIE and CLEAR.

\section{Card Retrieval Service}

Card Retrieval Service consists of 4 card files.

\section{Publication of Iron and Steel Technical Abstract}

A monthly abstract journal (a kind of current awareness bulletin) covering important Japanese and foreign journals, international convention proceedings and other information sources is published. This journal is available on yearly subscription basis with some reduction to ISIJ members.

\section{Cooperation with JICST}

JISTIC is in close cooperation with JICST in various ways. The most important field of cooperation is making of computer-readable abstracts for input of the JICST Metal File.

In 1980 JISTIC's input represented about $20 \%$ of this file. JISTIC's four specialists with assistance of outside collaborators are working for this task. JISTIC is looking ahead to enlarge this percentage further.

\section{Others}

(1) JISTIC periodically and occasionally organized lecture meetings, study groups, etc. for information and documentation specialists in the steel industry.

(2) JISTIC serves as the industry's representative for governmental agencies and international cooperation pertaining to information services.

(3) JISTIC is responsible for custody and documentation of the Institute's in-house technical papers. It almost completed a system of microfishing of the Joint Research Society Proceedings.

All activities mentioned above are carried out in accordance with decisions and recommendations made by the JISTIC Supervisory Committee which consists of representatives of several steel companies and some outside experts, and under it the three technical committees, namely, Editorial, Documentation and Retrieval Technique which consist respectively of company specialists.

Main tasks for these three committees are as follows:

(1) Editorial: Cooperation to the activity 4 mentioned already

(2) Documentation: Rationalization of custody measures of the ISIJ's in-house technical documents and recommendation of purchasing policy for enriching the library

(3) Retrieval Technique: Study and improvement of mechanical retrieval techniques and software related to them.

These committees were stepping up their activities with concrete results during 1980.

\section{ISO Secretariat}

\section{Secretariat of ISO/TC 17}

Since the official handover from the United Kingdom of the secretariatship of ISO/TG 17-Steel, in June 1979, the Japanese Secretariat Team has been performing its responsibilities, receiving much recognition from the ISO Central Secretariat and the parties concerned.

Since then 24 International Standards have been published. Among others, 6 standards were published based on revised DIS texts (revised texts for Draft International Standards) prepared by the Japanese Secretariat.

Following the nomination as a result of letter ballot by the P-Members of ISO/TG 17, Mr. Akira Aoki (Nippon Steel Corporation) has been appointed Chairman of the Technical Committee by the ISO Council for a three-year period (1981-1983).

At its meeting of the Executive Committee of ISO/ TG 17 held in Stockholm, Sweden, October 27 and 28 1980, Mr. Aoki also acted as Chairman, while Mr. Yoshinori Tanaka, Secretary of ISO/TG 17 acted as Secretary. The Committee discussed matters of principles relating to the activities of ISO/TG 17. Particularly there was active exchange of opinions on the restructuring of Sub-Committees of ISO/TG 17 and the coordination of work on steel tubes between ISO/TG 5-Metal pipes and fittings and ISO/ TG 17.

In addition to the above-mentioned activities, the Secretariat participated in the 7 international meetings of the Sub-Committees and the Advisory Group of ISO/TG 17.

The Secretariat also participated in the following 2 ISO international meetings as the representatives of ISO/17:

1) Coordination meeting of the secretariats of metals technical committees

2) Ad hoc meeting on the coordination of work on metal tubes

Further, the Secretariat attended the meeting of Working Party of CCG/HSC (Customs Co-operation 
Council/Harmonized System Committee) held in Brussels in December 1980, and expressed the views of ISO in relation to Harmonized Commodity Description and Coding System/Chapter 72: Pig Iron, Iron and Steel.

Other activities of the Secretariat in 1980 included the appointment of Japan as succeeding Secretariat of ISO/TG 17/SG 1-Methods of determination of chemical composition.

\section{Secretariat of $I S O / T C 17 / S C 1$}

(1) At the 13th Plenary Meeting of ISO/TG 17 in June 1979, delegates present approved the resignation of Ireland from the Secretariat of ISO/TC 17/ SC 1 (Methods of determination of chemical composition). It was decided to request the Secretariat of ISO/TG 17 (JISG) to carry out the responsibilities of this absent Secretariat.

(2) The Secretariat of ISO/TG 17 circulated a questionnaire among P-Member Bodies of TC 17 asking to undertake the secretariat responsibilities of ISO/TG 17/SG 1. Since Japan was the only volunteer, the Secretariat informed the members in June 1980, that Japan is to takeover the responsibilities, and announced the official opening of its office on September 1 .

(3) The Agency of Industrial Science and Technology of Japan entrusted the secretariat responsibilities of ISO/TG 17/SG 1 to ISIJ. Accordingly, ISIJ established the Secretariat and started the practical activities on July 1, on the 10th floor of Nippon Building Annex, Tokyo.

(4) The new Secretariat consists of two persons, Dr. Terumi Oda as the Secretary for SG 1 (dispatched from Sumitomo Metal Industries, Ltd.) and an assistant.

(5) In order to carry out the secretariat activities effectively, the Steering Committees under the chairmanship of Mr. Hisao Kitsunezaki, Nippon Steel Corp., and the Technical Advisary Subcommittee under the chairmanship of Dr. Kazuo Kawamura, Nippon Steel Corp., were set up.

(6) The Secretary visited Dublin, Ireland and ISO Central Secretariat to transfer the secretariatship of SC 1 and went to see members of BSI (the United Kingdom) and AFNOR (France) in order to ask their cooperation in the activities of SG 1 .

(7) The Secretary also participated, as an observer, in the Meeting of ISO/TG 102/SG 2 (chemical analysis of iron ore) held in South Africa to learn the procedure of ISO meetings relating to chemical analysis.

\section{International Activities}

1. The 1st Venezuela-Japan Symposium on Steelmaking

The first symposium between Venezuela and Japan on steelmaking was held in Caracas, Venezuela for 5 days from May 19. ISIJ sent a 11 member mission headed by Prof. Masayasu Ohtani (Director of Research Institute of Mineral Dressing and Metallurgy, Tohoku University). Dr. K. Takeda, President of ISIJ and Mr. S. Tabata, Executive Director of ISIJ also attended. Ten by Japanese and 13 by Venezuelan papers were presented and discussed. thereafter the delegates visited HIB Plant, Bolivar Mines, Leonic Power Station and SIDOR in Guayana area, and Corpozulia and CICAST Research Institute in Zuria area.

\section{South East Asia Iron and Steel Institute}

The Institute's meetings were held in New Castle, Australia in March and Singapore in September. Discussions were conducted on "Market Factors and their Effect on Steel Industry Development and Location" in the March meeting and "Prospects for Mini-Steel Mills" in the September meeting.

Both numbers of papers presented and participants at the meetings of this Institute are increasing each year; there were 28 papers and 280 participants at the Singapore meeting. Mr. Noboru Yanagoshi of Kobe Steel made a keynote lecture titled "Employment of Mini-mill ".

\section{The 1st International Conference on Steel Rolling}

ISIJ organized the Conference which was held at Keidanren Kaikan, Tokyo from September 29 to October 4. In the past there was no large scale conference devoted exclusively on rolling. This consideration led to the proposal coming from the several committees of ISIJ's Joint Research Society related to rolling technology to sponsor this conference in Japan. The main theme of the Conference was "Science and Technology of Flat Rolled Products" and the following 4 subjects were specified:

1) Profile and Shape Control and New Technique in Flat Rolling;

2) Lubrication in Flat Rolling;

3) Direct Rolling and Hot Charge Rolling, and

4) Conrtolled Rolling of Flat Products.

The Conference received a wide attention from Japanese and international organizations. The number of papers presented turned out to be 110 (62 from abroad), well over the expectation. The meeting was held in the following 8 sections with the participation of 480 persons in total (180 from abroad): (1) Direct Rolling and Hot Charge, (2) Plate, etc., (3) Shape Meter and New Technology, (4) Cold Strip Mill, (5) Cold and Hot Strip mill, (6) Controlled Rolling, (7) Lubrication and (8) Controlled Rolling and Controlled Cooling.

In addition, two keynote lectures and one invited lecture were given as follows:

(1) "Progress of Rolling Technology in Japan" By Dr. Nobuo Fukuda (Japan)

(2) "Contribution of Fundamental Research to Progress in Rolling Technology", By Prof. Dr.-Ing. Oskar Pawelski (Germany)

(3) "An Aspect of Metallurgical Problems on Controlled Rolling of Steel in Japan"

By Prof. Dr. Imao Tamura (Japan)

Following the adjournment of the Conference, participants from abroad visited 5 selected iron and steel works and rolling facilities fabricating plants. During the Conference, an exhibition was held in the same building with the participation of 15 iron and steel firms and the rolling machinery firms. 


\section{The 4th Germany-Japan Seminar}

This Seminar was held on November 12 and 13 at Keidanren Kaikan, Tokyo, to which the VDEh sent 12 delegates headed by Dr. A. Randak (Krupp Stahl A.G.) and Dr. K. Nürnburg (Executive Director of VDEh), with 109 participants. The subjects discussed were as follows.

(1) Metallurgical Kinetics of Iron and Steelmaking;

(2) Basic Principles of Solidification of Steel with Special Regard to Continuous Casting, such as

1) Reoxidation and Cleanness in Connection with Properties of Steel,

2) Electromagnetic Stirring and Formation of Equiaxed Crystal Zone,

3) Segregation, and

4) Secondary Cooling and Properties of the Frozen Shell

Following the Seminar the German delegates visited 6 steel plants and universities from November 14 to 21 .

5. Australian-Japan Extractive Metallurgy Symposium 1980

This Symposium was held in Sydney, Australia for three days from July 16. The Symposium was organized under the sponsorship of The Australasian Institute of Mining and Metallurgy. ISIJ and The Mining and Metallurgical Institute of Japan formed a joint deligation.

45 papers consisting of 24 from Japan (10 on iron and steel) and 21 papers from Australia (7 on iron and steel) were presented and discussed in 9 sections by 60 Japanese delegates headed by Mr. Goro Mori, President of The Mining and Metallurgical Institute of Japan, and 120 Australian participants. The keynote lectures were given as follows:

(1) "Trends in the Study of Physical Chemistry of Steelmaking",

By Prof. Tasuku Fuwa (Professor Emeritus of Tohoku University)

(2) "Copper Metallurgy and $\mathrm{SO}_{x}$ Problem in Japan",

By Prof. Dr. Jyoichiro Moriyama (Kyoto University)

The participants enjoyed the post-symposium plant visit in any one of the three courses, one on iron and steel and two on mining.

\section{The 4th Yukawa Memorial Colloquy}

The Colloquy was held for two days of April 5 and 6 at Hakone Prince Hotel. Mr. G. W. van Stein Callenfels, President of The Metals Society, who was awarded the Honorary Membership of ISIJ at the 65th General Assembly in April, 1980, and Japanese members, consisting of top technical executives representing major steel companies and headed by Dr. K. Takeda, ISIJ President, participated in the colloquy. Two subjects were selected as discussion themes.

1) Energy Problems, Natural Resources

2) Environmental Problems of Steel Industry

\section{Chinese Society of Metals Mission}

A ten member mission led by $\mathrm{Mr}$. Jun-Zhao $\mathrm{Fu}$, Managing Director of the Chinese Society of Metals, was invited to Japan by ISIJ for discussion and plant visits from March 31 to April 19. This invitation was extended as a return of the similar invitation the ISIJ mission (9 members led by Mr. S. Tabata, Executive Director of ISIJ) received in September 1979.

During their stay in Japan, the mission participated in the 65th ISIJ General Assembly and the 99th ISIJ Meeting on April 2 and 3. They also visited universities, research institutes and iron and steel plants in the vicinity of Tokyo, Nagoya and other parts of West of Japan. The mission presented the following papers during these visits:

(1) "Activities of Chinese Institute of Metals"

By Mr. Jun-Zhao Fu (Permanent Council Member of the Board of Directors, The Chinese Society of Metals)

(2) "Some Technological Development in the Chinese Steel Industry",

By Mr. Xiang-Hua Shao (Permanent Council Member of the Board of Directors, CSM)

(3) "Recent Researches on Extra-furnace Refining of Special Steels in China"

By Mr. Yu-Lung Kuan (Associate Professor of Beijing Institute of Iron and Steel)

(4) "Research on Phase Transformation of Amorphous Metals",

By Mr. Jing-Tang Wang (Associate Research Fellow of Shenyang Research Institute of Metals, The Academy of Science of China) 